\title{
STRUCTURAL E-PERMITS: AN OPENBIM, MODEL-BASED PROCEDURE FOR PERMIT APPLICATIONS PERTAINING TO STRUCTURAL ENGINEERING
}

\author{
Vittoria CIOTTA*, Angelo CICCONE, Domenico ASPRONE, \\ Gaetano MANFREDI, Edoardo COSENZA \\ Department of Structures for Engineering and Architecture, University of Naples Federico II, Naples, Italy
}

Received 31 October 2020; accepted 21 September 2021

\begin{abstract}
This paper investigates the creation and use of integrated IFC models to modernise traditional processes for applications to building authorities for structural engineering approvals and permits. First, we provide a brief overview of e-permit systems in the AEC sector, with the focus on solutions that implement openBIM standards like IFC, MVD, and IDM. Second, we conduct a study on the information requirements of Italy's seismic-authorisation processes relating specifically to the field of structural engineering. Third, we describe preliminary research on defining the structural engineering information that needs to be incorporated in the IFC format for e-permitting scopes. Fourth, we present our early work on the development of an MVD that would enable the automatic extraction of integrated IFC models. Fifth, we illustrate the reference workflow of the Str.E.Pe. project and propose a preliminary proof-of-concept that makes use of an IFC model, which has been integrated with structural information to support the activities of the building authority in Avellino. The officers there have developed a SWOT analysis using IFC models to assist them in assessing the compliance of structural projects with seismic requirements. Finally, the paper sets out additional research we intend to undertake and our conclusions.
\end{abstract}

Keywords: building permits, building approvals, structural engineering permits, openBIM, IFC, MVD.

\section{Introduction}

In recent years, the Architecture, Engineering and Construction (AEC) sector has undergone a gradual transition from a traditional to a BIM approach. The former deploys processes for the production, exchange and delivery of information which, essentially, consists of $2 \mathrm{D}$ representations of construction projects and requires manual human-based checks. Meanwhile, the latter: 1) focuses on "information management" (i.e., the management and production of information during the life-cycle of a built asset); 2) introduces novel processes for the implementation of information models; and 3) embraces principles of digitisation, collaboration and automation (Wang, 2014). Automated and semi-automated clash-detection processes, as well as model- and code-checks (performed with suitable software), contribute to the validation of data and help to guarantee the reliability of information models in relation to both interdisciplinary coordination and correspondence with the information requirements specified by clients (Lee et al., 2015). Recently, building regulators and Building Authority Bodies (BABs) across the globe have begun to modernise their traditional systems for permit applications (Eirinaki et al., 2018). Their proposals generally adopt an information- and document-management system that enables the reliance on paper-based practices to be reduced or, sometimes, replaced with digital submissions of application forms, 2D drawings, and reports containing technical specifications. These have commonly been referred to as "e-permitting" systems. BABs are currently examining the openBIM approach as a possible strategy for further improvement of their procedures (Shahi et al., 2019). There are good reasons for this, since the use of open model-based processes and automated code-checking tools would streamline and accelerate permit-application practices significantly (Muto, 2020; Whitell et al., 2020). In detail, Muto developed in 2020 the buildingSMART report on using openBIM in e-permitting procedures worldwide (Muto, 2020). The report highlights that there are examples of using the IFC standard ISO 16739-1:2018 (International Organization for Standardization [ISO], 2018) to deliver an informa-

${ }^{*}$ Corresponding author. E-mail: vittoria.ciotta@unina.it 
tion model. In this regard, IFC-based Model View Definitions (MVDs) and Information Delivery Manuals (IDMs) are essential since information definitions are required to enable the computer program to read and understand the content in order to perform automatic code-checking rules.

However, both in Muto's (2020) report and in the academic field, there are no studies on the development of open model-based processes to apply for permits that pertain specifically to the structural engineering discipline, such as the Italian permit of seismic authorization. This gap determines the lack of reference datasets of structural engineering information that IFC models should convey both to support e-permitting processes and to implement automated code-checking rules. There are, however, already examples of specific MVDs to support structural engineering activities, such as the Structural Analysis View (buildingSMART International, 2021e). In regard to the structural design, Ramaji and Memari (2018) propose the development of a new mechanism (IIE - Interpreted Information Exchange) for the automated creation of analytical models in IFC (i.e. Structural Analysis View), which would then be imported into a structural tool from other MVDs, such as the Coordination View. While there are examples of the development of an MVD to support the structural design, nothing has been produced for e-permitting processes that refer to the structural engineering discipline. Venugopal et al. (2012) point out that in the development of an MVD, alternative decisions and solutions are required since the IFC is semantically deficient in some aspects and presents problems in the typing of objects, instances, geometry, and relations, as well as the complexity inherent in the exchange of such information between applications. Additionally, the validation of BIM data against MVD requirements can present problems, including syntactic problems, semantic errors, and unwanted geometric transformations. In order to solve some of these issues, Lee et al. (2019) present a study of current knowledge on automated rule-based BIM data validation using the MVD. Finally, Santos et al. (2019) have investigated the possibility of developing and using an IDM and an MVD to support information exchanges for life cycle assessment (LCA) and life cycle cost (LCC) analysis.

\section{Problem statement}

This paper aims to compensate for the lack of both practical and academic reference procedures for IFC-based e-permitting in structural engineering. To this end, this paper presents the most prominent research findings of the Structural E-Permitting (Str.E.Pe.) project of our team at the University of Naples Federico II (Italy), ACCA Software, the Campania region, the Avellino $\mathrm{BAB}$, and the Municipality of Montemarano. This work has investigated the use of openBIM standards like IFC and MVDs for improving the processes involved in applying to BABs for structural engineering permits and approvals. The paper is organised into five sections. After the Introduction, Sec- tion 1 describes the Str.E.Pe. project and issues that this addressed. In Section 2, we present the reference dataset of information for the Italian permit of seismic authorization and explain how we defined it. In Section 3, we describe an initial study that defines property sets (Psets) and the early development of an associated MVD in relation to the content that must be integrated in the IFC format. Section 4 presents the Str.E.Pe. workflow and a preliminary proofof-concept that uses an IFC model integrated with structural information to support the activities of the Avellino building authority. Officers there have developed a SWOT analysis on the use of IFC models to assist them in assessing the compliance of structural projects with seismic requirements. Last section discusses forthcoming developments and sets out our conclusions.

\section{Overview of the use of BIM in e-permit systems and procedures in the built-environment sector}

The Regulatory Room (RR) of buildingSMART ${ }^{\circ}$, an international association that aims to expand the use of openBIM to countries around the world, has recently investigated how e-submission systems (or platforms) and procedures are deployed globally to apply for permits and approvals in the AEC industry. Its study was finalised and released in 2020 as the E-submission common guidelines for introducing BIM into building processes (Muto, 2020). This contains a number of interesting findings. In particular, information exchanges between BABs and AEC stakeholders often relate to more than one phase of the building process. Consequently, applications can be assigned to three main groups: 1) concept approvals and permits; 2) building approvals and permits; and 3) construction approvals and permits. E-submission systems (or platforms) have been in development globally since the early 2000 s. However, their use is still limited: the buildingSMART ${ }^{\circ}$ study has identified only five examples (set out in Table 1), and just one of these enables openBIM-based submissions. Unfortunately, however, the guidelines do not contain any insights into this particular procedure.

The few examples in the buildingSMART report commonly use the IFC standard ISO 16739-1:2018 (ISO, 2018) to deliver an information model. The study stresses the need to identify: the stakeholders involved (to answer the

Table 1. E-submission platforms in the AEC sector

\begin{tabular}{|l|l|c|c|}
\hline Country & Name & $\begin{array}{c}\text { Year came } \\
\text { into force }\end{array}$ & \multicolumn{1}{c|}{$\begin{array}{c}\text { Other } \\
\text { notes }\end{array}$} \\
\hline Singapore & CORENET & 2000 & $\begin{array}{l}\text { Accepted BIM } \\
\text { submissions from 2010 }\end{array}$ \\
\hline Norway & ByggSøk & 2003 & - \\
\hline Finland & $\begin{array}{l}\text { Tekra-GIS, } \\
\text { Lupapiste.fi }\end{array}$ & 2012 & - \\
\hline Korea & SEUMTER & 2002 & - \\
\hline Japan & - & 2015 & $\begin{array}{l}\text { Introduced for small } \\
\text { wooden houses }\end{array}$ \\
\hline
\end{tabular}


question "who?”); the exchange points (“when?"); and the information requirements ("which data?"). Interaction maps are used in the report to depict the exchanges with the e-submission platforms. Particular reference is made to the adoption of the Business Process Model and Notation (BPMN) language (which is also used for IDMs) to better describe the processes involved.

A gradual transition from a traditional to a BIM-based workflow is essential from a legal perspective. The buildingSMART ${ }^{\circ}$ study identifies four stages: manual, digital, hybrid and automated. Additionally, the degree to which Industry Foundation Class (IFC) property values are utilised determines three levels of development of BIM e-submission procedures: 1) visualisation - the value of the BIM property is not actively utilised; 2) hybrid/information flow - the value of the BIM property is actively adopted for specific code-checks; in this stage, IFC-based MVDs and IDMs are essential, since information definitions are required to enable the computer program to read and understand the content; and 3) automated codechecking - the value of the BIM property is used for holistic code-checking purposes; e-Low, a machine-readable building code, is required to achieve this.

Academic research is now focusing on e-submission processes and systems as well. Shahi et al. (2019), for example, have defined an e-permit reference framework with four levels of development: traditional permit; basic e-permit; automated model-based e-permit; and fully-integrated (BIM+GIS) e-permit. The Shahi's framework considers the impact of each level on the entire life-cycle of a project, i.e., from the submission of permit documentation through to the construction, operation and maintenance of the built facility. Shahi's team also clearly highlights that esubmission systems and procedures are a prolific research field when it comes to the use of automated model-based and fully-integrated BIM+GIS e-permit applications, and proposes a general reference framework for the adoption of openBIM standards in e-permitting (Shahi et al., 2019). Finally, the buildingSMART report also contains interesting guidelines for the implementation of openBIM-based procedures. Finally, the buildingSMART ${ }^{\circ}$ report and the study of Shahi et al. (2019) contain only a few examples of actual applications, none of which address the use of IFCbased MVDs and IDMs to support information exchanges with $B A B s$ in relation to structural engineering, whether in terms of workflows or of information requirements.

\section{The Structural E-Permit (Str.E.Pe.) project}

The Str.E.Pe. project concerns the 2019 award-winning (at buildingSMART International) research conducted by the University of Naples Federico II (Department of Structures for Engineering and Architecture) in collaboration with ACCA Software, the Campania region, the Avellino $\mathrm{BAB}$, and the Municipality of Montemarano. Those involved were tasked with creating an IFC-based approach for use throughout Italy in applications for a seismic-authorisation ("autorizzazione sismica") permit (note: this approval pertains mainly to the field of structural engineering). Although structural engineers are required to adhere to national building codes, they have to apply for approvals and permits to BABs, which verify them and enforce compliance. Unfortunately, the traditional practices involved in interactions with BABs typically consist of manual, paper-based processes that involve, for applicants, the time-consuming activities of printing documentation and completing application forms and checklists. An IFCbased approach could improve the traditional processes in countries like Italy, which are characterised by territories with high levels of seismicity and consequently pay great attention to structural design.

The Str.E.Pe. project is organized into three phases. In phase 1 , we addressed the lack of a reference dataset. We remedied this by analyzing national application practices for the seismic authorization permit in order to identify reference regulations and required deliverables. This highlighted that BABs have introduced summary checklists to be filled in by hand to speed up their countercheck procedures. Accordingly, we defined the reference dataset for seismic authorization from these summary checklists and concurrently thought of possible automated code-checking rules to implement. In phase 2, we defined our strategy to use the IFC format to apply for the seismic authorization permit: using the IFC format to reduce (not replace) required deliverables. Consequently, we studied the IFC format to understand whether this supports the structural engineering discipline and can convey the collected information of the reference dataset produced in phase 1 . Unfortunately, we discovered that only a few pieces of information could be conveyed, and we thus also identified possible ways of integrating information in the IFC format in order to exchange more information from the reference dataset, prioritizing the information that could support automatic code-checking rules. Finally, in phase 3 , we developed a reference workflow for the proposed IFC-based procedure which implements tools that ACCA Software had created. We also implemented a preliminary proof-of-concept of the proposed IFC-based procedure for the seismic authorization permit. The details of the three phases outlined above are set out in what follows.

\section{Phase 1}

\subsection{Analysis of the practices and deliverables required for seismic-authorisation applications in Italy}

The issue of seismic prevention is an extremely sensitive topic in Italy. As a result, the last few decades have seen the Italian government identify two features that require a simultaneous focus: classifying the entire country seismically based on the intensity and occurrence of previous seismic events; and developing specific reference standards for structures built in areas where there is seismic activity. In 2004, a study conducted by the Istituto Nazionale di Geofisica e Vulcanologia (INGV) concluded 
that the whole of Italy should be regarded as seismic. It therefore produced the seismic-hazard map shown in Figure 1, which portrays four different seismicity levels: low, medium, high and very high. Every Italian region must identify the appropriate level for each municipality under its jurisdiction and can enforce stricter seismic-risk regulations, if required. Currently, there are two types of building permit available for seismic areas in Italy (i.e., the entire country): a seismic deposit (in Italian: "deposito sismico"), which is required in areas of very low seismicity; and seismic authorisation, which is needed everywhere else. Each of these permit types has its own application practices. However, for reasons of brevity, our focus is on the second.

As an academic partner in the Str.E.Pe. project, we have undertaken the process of researching, organising and synthesising the seismic-authorisation application practices in all 20 Italian regions. Table 2 summarizes our research questions, main tasks and research findings.

In detail, we ascertained that all 20 regions have a process for applying for seismic-authorization permits. In general, a structural engineer (or his/her representative) acts on behalf of a client and applies for a permit to the $\mathrm{BAB}$ with jurisdiction over a project. Once the BAB receives the application, including any required deliverables (see Table 2), they are checked to ensure the suitability of the design and compliance with relevant building codes, such as the Italian building code Norme tecniche per le costruzioni - NTC 2018 (Ministero delle Infrastrutture e dei Trasporti, 2018). The BAB also oversees the application technically and administratively. If the procedure has a positive outcome, meaning no revisions are required, the $\mathrm{BAB}$ grants the seismic-authorization permit, which enables the building process to advance to the construction phase. Alternatively, the BAB may ask for changes, which will require the submission of supplemental materials and revisions until it is satisfied. When the demands of the seismic-authorization application process have been met, the $\mathrm{BAB}$ must issue a building permit within 60 days. Our investigation identified that only $40 \%$ of Italian regions have online permitting (i.e., e-permitting) platforms, although some allow engineers to choose between a manual paper-based process and an online version. The remaining $60 \%$ still rely on manual practices. Moreover, $25 \%$ of regions require applicants to complete additional checklists and/or forms summarizing the data on a project. These forms and checklists may vary depending on the type of structure: some differ according to the construction system (reinforced concrete, masonry, steel, or wood) and the kind of intervention (new or existing buildings), while others have just a single format that is suitable for all cases. None of the regions employs procedures that accept BIM models, even when online permitting systems are available.

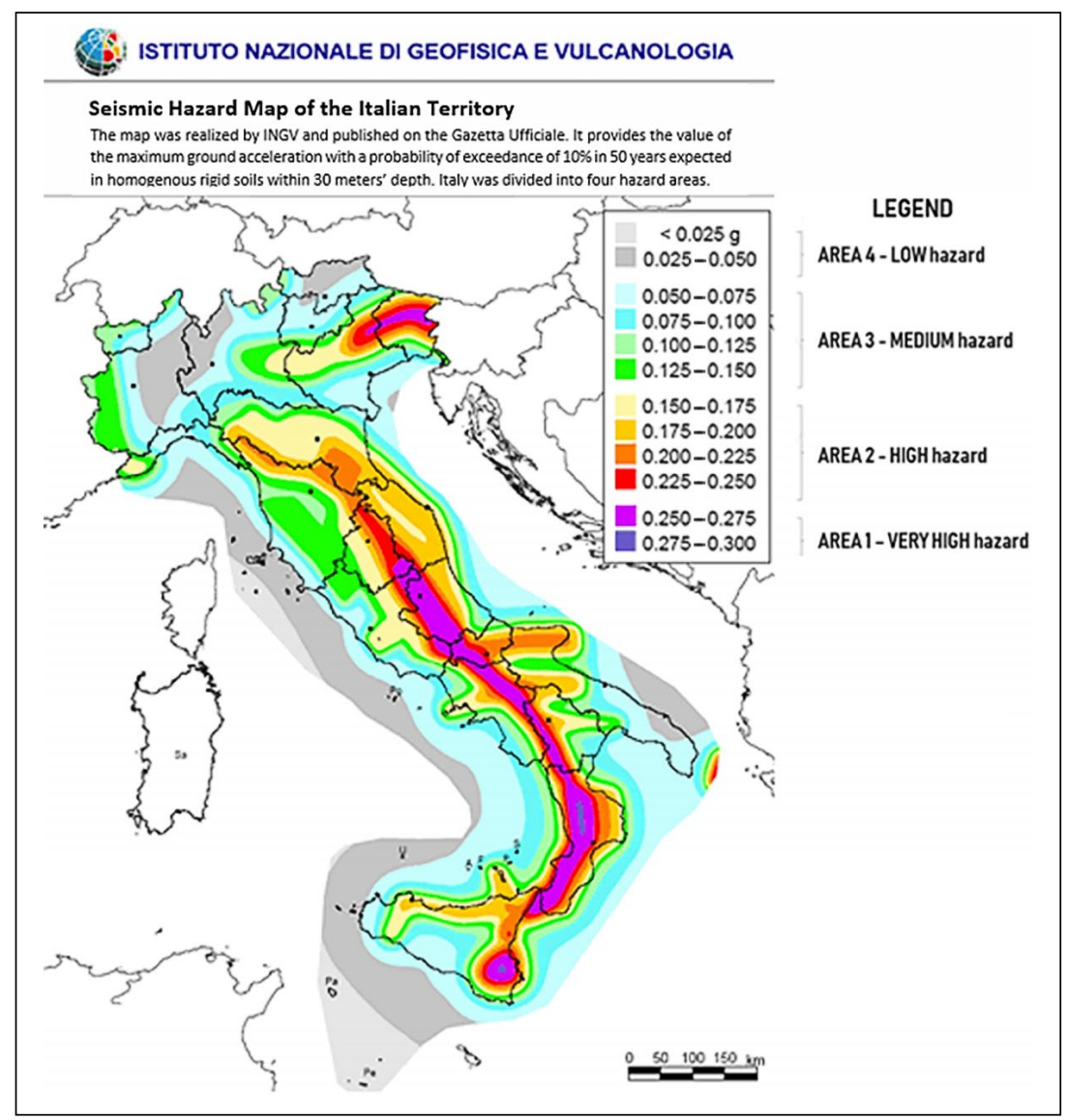

Figure 1. The seismic hazard map of the territory of Italy (Istituto Nazionale di Geofisica e Vulcanologia, n.d.). 
Table 2. Summary of the process of researching, organising and synthesising the seismic-authorisation application practices in all 20 Italian regions

\begin{tabular}{|c|c|c|}
\hline Research questions & Tasks undertaken & Research findings \\
\hline $\begin{array}{l}\text { 1. Do all Italian regions have a pro- } \\
\text { cess for applying for a seismic- } \\
\text { authorisation permit? }\end{array}$ & $\begin{array}{l}\text { Internet searches on official websites for } \\
\text { each region that describe the procedures for } \\
\text { applying for a seismic-authorisation permit. } \\
\text { Obtaining guidelines and instructions that } \\
\text { describe the documentation required to apply } \\
\text { for a seismic-authorisation permit in each } \\
\text { region. } \\
\text { Downloading the application forms available } \\
\text { on the websites. }\end{array}$ & $\begin{array}{l}100 \% \text { of Italian regions have a process for } \\
\text { applying for a seismic-authorisation permit. } \\
\text { Official websites provide both application } \\
\text { forms to download and instructions to follow. }\end{array}$ \\
\hline $\begin{array}{l}\text { 2. Does any Italian region have an } \\
\text { online permitting platform for } \\
\text { applying for a seismic-authorisa- } \\
\text { tion permit? }\end{array}$ & $\begin{array}{l}\text { In-depth analysis of the instructions available } \\
\text { on the official websites of all } 20 \text { Italians } \\
\text { regions. }\end{array}$ & $\begin{array}{l}40 \% \text { of Italian regions have an online } \\
\text { permitting procedure vs. } 60 \% \text { that still rely on } \\
\text { manual processes. }\end{array}$ \\
\hline $\begin{array}{l}\text { 3. Which deliverables are required } \\
\text { when applying for a seismic- } \\
\text { authorisation permit? Are BIM } \\
\text { models considered? }\end{array}$ & $\begin{array}{l}\text { Analysis of the guidelines and instructions } \\
\text { (obtained as explained in point } 2 \text { above) that } \\
\text { describe the documentation needed to apply } \\
\text { for a seismic-authorisation permit in each } \\
\text { region. }\end{array}$ & $\begin{array}{l}\text { The deliverables comprise, at most: } \\
\text { - Application form; } \\
\text { - 2D drawings; } \\
\text { - Reports with technical specifications; } \\
\text { - A building permit issued by the municipal- } \\
\text { ity with jurisdiction over the area where a } \\
\text { project is to be located; } \\
\text { - Additional checklists and forms summaris- } \\
\text { ing a project's structural technical specifica- } \\
\text { tions. } \\
\text { There is no mention of BIM models. }\end{array}$ \\
\hline $\begin{array}{l}\text { 4. Does any Italian region require } \\
\text { the completion of additional } \\
\text { checklists and/or forms that } \\
\text { summarise the data concerning } \\
\text { the structural project? }\end{array}$ & $\begin{array}{l}\text { Analysis of guidelines and instructions (as } \\
\text { above) that describe the documentation } \\
\text { needed to apply for a seismic-authorisation } \\
\text { permit in all regions. }\end{array}$ & $\begin{array}{l}\text { The } 25 \% \text { of Italian regions have additional } \\
\text { checklists or forms that must be completed } \\
\text { manually. }\end{array}$ \\
\hline
\end{tabular}

It is notable that, as highlighted above, no Italian region has ever addressed the possibility of using BIM models in seismic-authorisation applications, and nor is there any example of their employment internationally. In Italy, alternatives to the (manual) submission of paper documentation involve e-permitting systems where deliverables corresponding precisely to these documents can be uploaded in the PDF format. Clearly, this is nothing more than the replacement of paper documentation with a digital equivalent and does not enable the implementation of any substantial automated controls during the application process.

\subsection{An overview of international building-approval and permitting practices relating to structural engineering}

"Performance standards" form part of seismic regulations worldwide, compliance with which protects engineering practitioners in relation to their legal responsibilities, without depriving them of discretion and autonomy. In Italy, the technical requirements are, to some extent, embedded in legal standards, thus becoming binding prescriptions. Local authorities may also have the power to introduce additional requirements to ensure code compliance. Given the huge number and wide variety of building work approval practices in place globally, Table 3 provides an overview of several countries of interest, setting out what is known of their authorization processes in relation to structural and seismic designs. In detail, we describe reference building codes and the main enforcement strategies for New Zealand, California (USA) and Greece, all of which, along with Italy, have played a prominent role in developing the field of seismic engineering (Reitherman, 2012).

\subsection{Identifying the reference dataset of information to support seismic-authorisation applications}

In order to identify the information that the IFC format would need to manage, we analysed the checklists and forms we had obtained in Section 3.1, producing a comprehensive dataset that would satisfy the information requirements of all the Italian BABs. Table 4 sets out the data identified by our study in relation to new reinforced concrete structures.

The first column in Table 4 contains a reference that assists with the organization of the data. We have defined nine main sections: 1) description of the project; 2) properties of the foundation ground; 3 ) design actions (gravity loads, earthquake, snow, wind, etc.); 4) design criteria and modelling assumptions; 5) material properties; 6) structural-analysis methods and outcomes of the analyses; 7) structural-safety assessments for reinforced concrete structures; 8 ) structural-safety assessments of the foundations; and 9) construction details for reinforced concrete structures. 
Table 3. Summary of reference building codes and enforcement strategies in New Zealand, California and Greece

\begin{tabular}{|c|c|c|}
\hline Country & Reference building code & Considerations \\
\hline $\begin{array}{l}\text { New } \\
\text { Zealand }\end{array}$ & $\begin{array}{l}\text { The primary legislation governing the } \\
\text { construction industry is set out in the Building } \\
\text { Act } 2004 \mathrm{n}^{\circ} 72 \text { (Government New Zealand, } \\
\text { n.d.) which was enacted by the Ministry of } \\
\text { Business Innovation and Employment. } \\
\text { The minimum performance standards that } \\
\text { must be met are defined in Schedule } 1 \text { of the } \\
\text { building code (Seismic Resilience, n.d.). This is } \\
\text { a performance-based standard that allows more } \\
\text { than one way for the legislation's requirements } \\
\text { to be met. }\end{array}$ & $\begin{array}{l}\text { Territorial authorities (for instance, local councils) are empowered to } \\
\text { control the building activity in their district and to oversee a consent } \\
\text { process that enables building work to start. If they are registered as } \\
\text { Building Consent Authorities (BCAs), they also ensure compliance } \\
\text { with the building code. } \\
\text { Although the building code is a performance-based system, it allows } \\
\text { territorial authorities to introduce additional requirements to ensure } \\
\text { compliance, for example in relation to the verification method or } \\
\text { acceptable solutions. Designers can submit an alternative if they } \\
\text { can demonstrate to the BCA that the proposal will comply with the } \\
\text { building code. }\end{array}$ \\
\hline $\begin{array}{l}\text { California } \\
\text { (USA) }\end{array}$ & $\begin{array}{l}\text { The California Building Standards Code } \\
\text { (CBSC) was published in 2016. This sets out } \\
\text { the basis for the design and construction of } \\
\text { buildings in the state and is upheld by the } \\
\text { California Building Standards Commission } \\
\text { (n.d.). }\end{array}$ & $\begin{array}{l}\text { In relation to approval practices, the Building Division (or Building } \\
\text { Department) ensures compliance with standards by: setting out } \\
\text { procedures for reviewing and approving plans and specifications; } \\
\text { issuing permits; and conducting building inspections. } \\
\text { When it comes to local jurisdictions, each city or town can modify } \\
\text { the CBSC if it requires more restrictive dispositions. An example is } \\
\text { Los Angeles which provides check-lists (dubbed standard correction } \\
\text { lists) that are intended to facilitate and guide an interested party } \\
\text { through the permit process (Los Angeles Department of Building } \\
\text { and Safety, n.d.). There is a further process for structures in seismic } \\
\text { areas: the buildings that contain devices like isolators are also } \\
\text { subject to a "structural seismic peer review protocol" which requires } \\
\text { a descriptive document on the process. }\end{array}$ \\
\hline Greece & 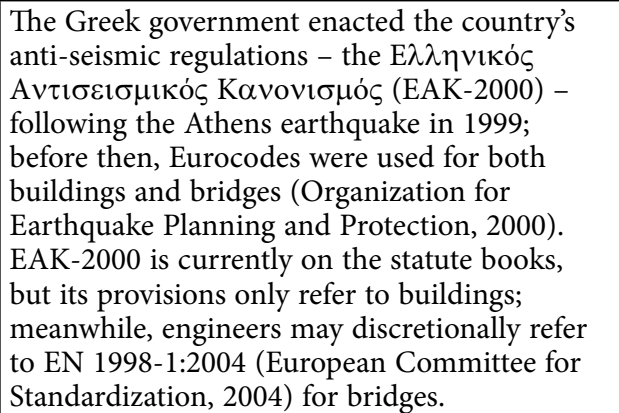 & $\begin{array}{l}\text { A new approval system for private work has been in place since } 2010 \\
\text { and aims to reduce bureaucracy. In addition, the delivery of project } \\
\text { documents in a digital format has recently become mandatory. } \\
\text { Municipal disciplinary committees take charge only when it comes } \\
\text { to assessing the completeness and accuracy of project-delivery } \\
\text { documentation (plans and technical specifications); ensuring that } \\
\text { projects comply with the reference code is the responsibility of } \\
\text { structural engineers. }\end{array}$ \\
\hline
\end{tabular}

Table 4. All the information sought by building authorities in applications for seismic-authorisation permits for new reinforced concrete structures

\begin{tabular}{|c|c|c|c|c|}
\hline ID & Brief description of information & Data type & Value & Source \\
\hline 1.1 & Brief description of the work & String & - & Enginee \\
\hline 1.2 & Land register data & String & - & Enginee \\
\hline 1.3 & Name of the owner & String & - & Enginee \\
\hline 1.4 & Geographical coordinates (latitude; longitude) & Number & - & Enginee \\
\hline 1.5 & Peak ground acceleration at the site of the work $\left(a_{g}\right)$ & Number & - & FEM \\
\hline 1.6 & $\begin{array}{l}\text { Existence of any proscriptions and/or urban } \\
\text { constraints }\end{array}$ & Boolean & Yes/no & Engineer \\
\hline 1.7 & Kind of work & String & Public/private/bonded (historical) & Enginee \\
\hline 1.8 & Type of work & String & $\begin{array}{l}\text { Ordinary building/industrial } \\
\text { warehouse/geotechnical work/ } \\
\text { other }\end{array}$ & Enginee \\
\hline 1.9 & Construction system & String & $\begin{array}{l}\text { Reinforced concrete/steel/ } \\
\text { masonry/wood/mixed }\end{array}$ & FEM \\
\hline 1.9 .1 & Existence of any seismic device (isolators/dampers) & Boolean & Yes/no & Enginee \\
\hline 1.10 & Type of bearing structure & String & $\begin{array}{l}\text { Frame (beams-columns/ walls/ } \\
\text { mixed/other) }\end{array}$ & FEM \\
\hline 1.11 & Type of foundation & String & $\begin{array}{l}\text { Shallow footings (combined, } \\
\text { spread, raft)/deep footings (piles)/ } \\
\text { jet grouting/other }\end{array}$ & Enginee \\
\hline
\end{tabular}


Continue of Table 4

\begin{tabular}{|c|c|c|c|c|}
\hline ID & Brief description of information & Data type & Value & Source \\
\hline 1.12 & $\begin{array}{l}\text { Construction category of use: residential, commercial, } \\
\text { offices, parking, etc. }\end{array}$ & String & $\begin{array}{l}\text { Categories from A to K according } \\
\text { to } \$ 2.5 .2 \text { NTC } 2018\end{array}$ & FEM \\
\hline 1.13 & $\begin{array}{l}\text { List of main geometrical information: total plan } \\
\text { surface area }\left[\mathrm{m}^{2}\right] ; \text { total volume }\left[\mathrm{m}^{3}\right] \text {; basement floors } \\
{\left[\mathrm{n}^{\circ}\right] \text {; storeys }\left[\mathrm{n}^{\circ}\right] ; \text { max floor span }[\mathrm{m}] ; \text { max depth of }} \\
\text { the footings }[\mathrm{m}] ; \text { max height of the roof }[\mathrm{m}] ; \text { other }\end{array}$ & Chart & - & FEM \\
\hline 2.1 & Ground investigation type & String & $\begin{array}{l}\text { Geotechnical tests/geophysical } \\
\text { tests (direct or indirect)/other }\end{array}$ & Engineer \\
\hline 2.2 & $\begin{array}{l}\text { Ground type, accounting for the influence of local } \\
\text { ground conditions on the seismic action }\end{array}$ & String & $\begin{array}{l}\text { Categories from A to S2 according } \\
\text { to } \$ 3.2 .2 \text { NTC2018 }\end{array}$ & FEM \\
\hline 2.3 & $\begin{array}{l}\text { List of ground parameters: } \mathrm{v}_{\mathrm{s} 30}[\mathrm{~m} / \mathrm{s}] ; \mathrm{N}_{\mathrm{spt} 30},[-] ; \mathrm{c}_{\mathrm{u}} \\
{[\mathrm{kPa}]}\end{array}$ & Chart & - & FEM \\
\hline 2.4 & Type of ground according to topographical conditions & String & $\begin{array}{l}\text { Categories from T1 to T5 } \\
\text { according to } \$ 3.2 .2 \text { NTC2018 }\end{array}$ & FEM \\
\hline 2.5 & Existence of liquefaction phenomena & Boolean & Yes/no & FEM \\
\hline 2.6 & $\begin{array}{l}\text { List of data that define the ground profile } \\
\text { stratigraphically: soil layers }\left[\mathrm{n}^{\circ}\right] ; \text { soil layer depth }[\mathrm{m}] \\
\text { soil weight } \Upsilon\left[\mathrm{kN} / \mathrm{m}^{3}\right] ; \mathrm{N}_{\mathrm{SPT}}\left[\mathrm{n}^{\circ}\right] ; \mathrm{q}_{\mathrm{c}}{ }^{\mathrm{CPT}}\left[\mathrm{kN} / \mathrm{m}^{2}\right]\end{array}$ & Chart & - & FEM \\
\hline 2.7 & Existence of aquifer & Boolean & Yes/no & FEM \\
\hline 3.1 .1 & $\begin{array}{l}\text { List of all design actions: type (self-weight, imposed } \\
\text { by category usage, wind, earthquake, snow, thermal, } \\
\text { etc.); name; brief description }\end{array}$ & Chart & - & FEM \\
\hline 3.1 .2 & $\begin{array}{l}\text { List of characteristic values of the design actions } \\
\left(\text { in } \mathrm{kN} / \mathrm{m}^{2}\right) \text { with respect to storeys, stairs, roofs, } \\
\text { foundations, other }\end{array}$ & Chart & - & FEM \\
\hline 3.1 .3 & $\begin{array}{l}\text { List of load combinations considered: load } \\
\text { combination name; list of loads involved; notes }\end{array}$ & Chart & - & FEM \\
\hline 3.2 .1 & Nominal service life of the structure $v_{N}$ [years] & Number & $\begin{array}{l}\text { Minimum values according to } \\
\S 2.4 .1 \text { NTC } 2018\end{array}$ & FEM \\
\hline 3.2 .2 & Importance of the structure: class and factor & $\begin{array}{l}\text { String and } \\
\text { number }\end{array}$ & $\begin{array}{l}\text { Classes from I to IV according to } \\
\$ 2.4 .3 \text { NTC } 2018\end{array}$ & FEM \\
\hline 3.2 .3 & Designed service life of the structure $\mathrm{v}_{\mathrm{R}}$ [years] & Number & $\begin{array}{l}\text { Value obtained according to the } \\
\text { formula [2.4.1] NTC2018 }\end{array}$ & FEM \\
\hline 3.2 .4 & Existence of a local seismic-response study & Boolean & Yes/no & Engineer \\
\hline 3.2 .5 & Response spectra data according to the limit state & Chart and plot & - & FEM \\
\hline 4.1 & $\begin{array}{l}\text { List of main geometrical data: } \mathrm{n}^{\circ} \text { of storeys; } \mathrm{n}^{\circ} \text { of } \\
\text { spans; inter-storey height; other }\end{array}$ & Chart & - & \\
\hline 4.2 & Existence of secondary structural elements & Boolean & Yes/no & Engineer \\
\hline 4.3 & Existence of noteworthy second-order effects & Boolean & $\begin{array}{l}\text { Yes/no (according to } \$ 7.3 .1 \mathrm{NTC} \\
\text { 2018) }\end{array}$ & FEM \\
\hline 4.4 & $\begin{array}{l}\text { Type of base constraints for primary structural } \\
\text { elements }\end{array}$ & String & - & FEM \\
\hline 4.5 .1 & Type of structural analysis in cases of seismic action & String & - & FEM \\
\hline 4.5 .2 & Ductility class & String & $\begin{array}{l}\text { High/low/not dissipative structural } \\
\text { behaviour }\end{array}$ & FEM \\
\hline 4.5 .3 & Satisfied structural regularity in plan & Boolean & Yes/no & FEM \\
\hline 4.5 .4 & Satisfied structural regularity in elevation & Boolean & Yes/no & FEM \\
\hline 4.5 .5 & Capacity design & Boolean & Yes/no & FEM \\
\hline 4.5 .6 & $\begin{array}{l}\text { Reinforced concrete structural element capacity } \\
\text { assessment, taking into account confinement effects } \\
\text { (according to } \$ 7.4 .1 \text { NTC2018) }\end{array}$ & String & - & FEM \\
\hline 4.5 .7 .1 & $\begin{array}{l}\text { Structural type of concrete building }(\$ 7.3 .1 \text { - Table } \\
\text { 7.3.II NTC2018) }\end{array}$ & String & - & FEM \\
\hline 4.5.7.2 & $\begin{array}{l}\text { Structural type of pre-cast building ( } \$ 7.3 .1 \text { - Table } \\
\text { 7.3.II NTC2018) }\end{array}$ & String & - & FEM \\
\hline
\end{tabular}


Continue of Table 4

\begin{tabular}{|c|c|c|c|c|}
\hline ID & Brief description of information & Data type & Value & Source \\
\hline 4.5 .7 .3 & $\begin{array}{l}\text { Structural type of steel or composite steel-concrete } \\
\text { buildings (\$7.3.1 - Table 7.3.II NTC2018) }\end{array}$ & String & - & FEM \\
\hline 4.5.7.4 & $\begin{array}{l}\text { Structural type of masonry building ( } \$ 7.3 .1-\text { Table } \\
\text { 7.3.II NTC2018) }\end{array}$ & String & - & FEM \\
\hline 4.5 .8 & $\begin{array}{l}\text { Behaviour factors for horizontal seismic actions } \\
\text { according to each limit state }\end{array}$ & Chart & - & FEM \\
\hline 4.5 .9 & $\begin{array}{l}\text { Assumption of diaphragmatic behaviour at the storey } \\
\text { level }\end{array}$ & Boolean & Yes/no & FEM \\
\hline 4.5 .10 & Existence of discontinued vertical structural elements & Boolean & Yes/no & FEM \\
\hline 4.5 .11 & Existence of noteworthy vertical seismic actions & Boolean & Yes/no & FEM \\
\hline 5.1 & $\begin{array}{l}\text { List of foundation concrete properties: concrete class; } \\
\text { characteristic compressive strength; Young's modulus; } \\
\text { design compressive strength }\end{array}$ & Chart & - & FEM \\
\hline 5.2 & $\begin{array}{l}\text { List of building concrete properties: concrete class; } \\
\text { characteristic compressive strength; Young's modulus; } \\
\text { design compressive strength }\end{array}$ & Chart & - & FEM \\
\hline 5.3 & $\begin{array}{l}\text { List of reinforcing steel properties: steel type; } \\
\text { characteristic yield tensile strength; characteristic } \\
\text { ultimate tensile strength; Young's modulus; design } \\
\text { tensile strength }\end{array}$ & Chart & - & FEM \\
\hline 5.4 & $\begin{array}{l}\text { List of pre-cast concrete properties: concrete class; } \\
\text { characteristic compressive strength; Young's modulus; } \\
\text { design compressive strength, other }\end{array}$ & Chart & - & FEM \\
\hline 5.5 & $\begin{array}{l}\text { List of pre-stressing steel properties: steel type; } \\
\text { characteristic ultimate tensile strength; characteristic } \\
\text { yield tensile strength; Young's modulus; other }\end{array}$ & Chart & - & FEM \\
\hline 5.6 & $\begin{array}{l}\text { List of structural steel properties: steel class; } \\
\text { characteristic yield tensile strength; characteristic } \\
\text { ultimate tensile strength; Young's modulus; design } \\
\text { tensile strength }\end{array}$ & Chart & - & FEM \\
\hline 5.7 & $\begin{array}{l}\text { List of masonry properties: masonry type; } \\
\text { characteristic compressive strength; characteristic } \\
\text { shear strength; Young's modulus; shear modulus; other }\end{array}$ & Chart & - & FEM \\
\hline 6.1 .1 & Fundamental vibration period of the structure & Number & - & FEM \\
\hline 6.1 .2 & $\begin{array}{l}\text { Requirements for linear static analysis (lateral force } \\
\text { method) according to } \$ 7.3 .3 .2 \text { NTC } 2018\end{array}$ & Boolean & Yes/no & FEM \\
\hline 6.1 .3 & $\begin{array}{l}\text { Consideration of accidental torsional effects ( } \$ 7.3 .3 \\
\text { NTC2018) }\end{array}$ & Boolean & Yes/no & FEM \\
\hline 6.2 .1 & $\begin{array}{l}\text { Number of modes considered for which the sum of } \\
\text { the effective modal mass amounts to at least } 85 \% \\
(\$ 7.3 .3 .1 \text { NTC2018) }\end{array}$ & Number & - & FEM \\
\hline 6.2 .2 & $\begin{array}{l}\text { Consideration of accidental torsional effects ( } \$ 7.3 .3 \\
\text { NTC2018) }\end{array}$ & Boolean & Yes/no & FEM \\
\hline 6.2 .3 & $\begin{array}{l}\text { Summary chart of modal information: fundamental } \\
\text { periods in the main horizontal directions of the } \\
\text { building; effective modal masses; and maximum roof } \\
\text { displacements }\end{array}$ & Chart & - & FEM \\
\hline 6.3 .1 & $\begin{array}{l}\text { Type of "uniform pattern" vertical distributions of } \\
\text { lateral loads applied according to } \$ 7.3 .4 .2 \text { NTC } 2018\end{array}$ & String & - & FEM \\
\hline 6.3 .2 & $\begin{array}{l}\text { Type of “modal pattern" vertical distributions of } \\
\text { lateral loads applied according to } \$ 7.3 .4 .2 \text { NTC } 2018\end{array}$ & String & - & FEM \\
\hline 6.3 .3 & $\begin{array}{l}\text { Consideration of accidental torsional effects }(\$ 7.3 .3 \\
\text { NTC2018) }\end{array}$ & Boolean & Yes/no & FEM \\
\hline 6.3 .4 & $\begin{array}{l}\text { Capacity curves and bilinear relationship data } \\
\text { according to } \$ 7.8 .1 .6 \text { NTC2018 }\end{array}$ & Chart and plot & - & FEM \\
\hline 6.4 & Non-linear dynamic analysis & String & - & Engineer \\
\hline 7.1 & $\begin{array}{l}\text { Footing assessment procedure and corresponding } \\
\text { safety factors for actions, materials and capacities }\end{array}$ & String & According to $\$ 6.2 .4 .1$ NTC 2018 & FEM \\
\hline
\end{tabular}


End of Table 4

\begin{tabular}{|c|c|c|c|c|}
\hline ID & Brief description of information & Data type & Value & Source \\
\hline 7.2 & $\begin{array}{l}\text { Safety checks performed in cases of shallow } \\
\text { foundations at the ultimate and serviceability limit } \\
\text { states (ULS and SLS) }\end{array}$ & \multirow{2}{*}{$\begin{array}{l}\text { Chart: each type } \\
\text { of check }\left(^{*}\right) \text { is } \\
\text { associated with } \\
\text { a minimum } \\
\text { value of the } \\
\text { capacity } \\
\text { demand ratio } \\
(\mathrm{C} / \mathrm{D}) \text { and } \\
\text { ID of the } \\
\text { corresponding } \\
\text { element }\end{array}$} & $\begin{array}{l}\left.{ }^{*}\right) \text { Bearing resistance/sliding } \\
\text { resistance/overall stability/ } \\
\text { structural/ settlements/other }\end{array}$ & FEM \\
\hline 7.3 & $\begin{array}{l}\text { Safety checks performed in cases of deep foundations } \\
\text { at the ultimate and serviceability limit states (ULS and } \\
\text { SLS) }\end{array}$ & & & FEM \\
\hline 7.4 & $\begin{array}{l}\text { Checks performed on the horizontal connections at } \\
\text { the foundation level }\end{array}$ & Boolean & Yes/no & FEM \\
\hline 8.1 .1 & $\begin{array}{l}\text { List of safety checks required for each limit state } \\
\text { according to the class of building }\end{array}$ & Chart & $\begin{array}{l}\text { Available options according to } \\
\text { \$7.3.6 NTC } 2018\end{array}$ & FEM \\
\hline 8.1.2.1 & $\begin{array}{l}\text { ULS WITHOUT seismic actions: safety checks } \\
\text { performed on cross-sections of primary structural } \\
\text { elements such as beams, columns and walls }\end{array}$ & \multirow{3}{*}{$\begin{array}{l}\text { Chart: each type } \\
\left.\text { of check }{ }^{\star}\right) \text { is } \\
\text { associated with } \\
\text { a minimum } \\
\text { value of the } \\
(\mathrm{C} / \mathrm{D}) \text { ratio } \\
\text { and ID of the } \\
\text { corresponding } \\
\text { element }\end{array}$} & $\begin{array}{l}\left(^{*}\right) \text { Axial load/bending moment/ } \\
\text { shear/torsion/ punching/buckling/ } \\
\text { combined checks/other }\end{array}$ & FEM \\
\hline 8.1 .2 .2 & $\begin{array}{l}\text { ULS (life safe) in the case of seismic actions: safety } \\
\text { checks performed on cross-sections of primary } \\
\text { structural elements such as beams, columns and walls }\end{array}$ & & $\begin{array}{l}\left(^{*}\right) \text { axial load/bending moment/ } \\
\text { shear/torsion/ punching/buckling/ } \\
\text { combined checks/other }\end{array}$ & FEM \\
\hline 8.1 .2 .3 & $\begin{array}{l}\text { ULS (near collapse) in the case of seismic actions: } \\
\text { safety checks performed on cross-sections of primary } \\
\text { structural elements such as beams, columns and walls }\end{array}$ & & Ductility checks/other & FEM \\
\hline 8.1 .3 & $\begin{array}{l}\text { Safety checks performed on secondary structural } \\
\text { elements }(\$ 7.2 .3 \text { NTC2018) }\end{array}$ & Boolean & Yes/no & FEM \\
\hline 8.1 .4 & $\begin{array}{l}\text { Safety checks performed on non-structural elements } \\
(\$ 7.2 .3 \text { NTC2018) }\end{array}$ & Boolean & Yes/no & FEM \\
\hline 8.1 .5 & Safety checks performed on systems (\$7.2.3 NTC2018) & Boolean & Yes/no & FEM \\
\hline 8.1 .6 .1 & $\begin{array}{l}\text { SLS WITHOUT seismic actions: safety checks } \\
\text { performed on cross-sections of primary structural } \\
\text { elements such as beams, columns and walls }\end{array}$ & \multirow{3}{*}{$\begin{array}{l}\text { Chart: each type } \\
\text { of check }\left(^{*}\right) \text { is } \\
\text { associated with } \\
\text { a minimum } \\
\text { value of the } \\
\text { C/D ratio } \\
\text { and ID of the } \\
\text { corresponding } \\
\text { element }\end{array}$} & $\begin{array}{l}\left(^{*}\right) \text { Axial load/bending moment/ } \\
\text { shear/torsion/ punching/buckling/ } \\
\text { combined checks/other }\end{array}$ & FEM \\
\hline 8.1 .6 .2 & $\begin{array}{l}\text { SLS (immediate occupancy) in the case of seismic } \\
\text { actions: safety checks performed on cross-sections of } \\
\text { primary structural elements such as beams, columns } \\
\text { and walls }\end{array}$ & & $\begin{array}{l}\left(^{*}\right) \text { Axial load/ bending moment/ } \\
\text { shear/torsion/punching/buckling/ } \\
\text { combined checks/other }\end{array}$ & FEM \\
\hline 8.1 .6 .3 & $\begin{array}{l}\text { SLS (operational) in the case of seismic actions: } \\
\text { safety checks performed on cross-sections of primary } \\
\text { structural elements such as beams, columns and walls }\end{array}$ & & $\begin{array}{l}\left(^{*}\right) \text { Axial load/bending moment/ } \\
\text { shear/torsion/punching/buckling/ } \\
\text { combined checks/other }\end{array}$ & FEM \\
\hline 8.1 .7 & $\begin{array}{l}\text { Checks of the available distance between adjacent } \\
\text { constructions ( } \$ 7.2 .1 \text { NTC2018) }\end{array}$ & Boolean & Yes/no & FEM \\
\hline 9.1 & $\begin{array}{l}\text { Satisfied geometrical constraints for beams, columns, } \\
\text { walls and beam-column joints according to } \\
\text { \$7.4.6.1.1-4 NTC2018 }\end{array}$ & Boolean & Yes/no & FEM \\
\hline 9.2 & $\begin{array}{l}\text { Type of reinforcement constraint satisfied for each } \\
\text { primary structural element inside and outside the } \\
\text { critical region }\end{array}$ & $\begin{array}{l}\text { Chart: each type } \\
\text { of constraint } \\
\left({ }^{*}\right) \text { is associated } \\
\text { with a } \\
\text { minimum value } \\
\text { of the required/ } \\
\text { effective ratio } \\
\text { of the requested } \\
\text { quantity }\end{array}$ & - & FEM \\
\hline 9.3 & $\begin{array}{l}\text { Critical region minimum length satisfied (with respect } \\
\text { to each structural element) according to } \$ 7.4 .6 .1 .1-4 \\
\text { NTC2018 }\end{array}$ & Boolean & Yes/no & FEM \\
\hline
\end{tabular}


Columns two to five contain, respectively, a brief description of the information required, the data type, a list of possible values (if any), and the information source. The data type includes strings of characters, numbers and Boolean-type data (true or false). We also provide the source of the information, ranging from FEA software to data added manually by a structural engineer.

\section{Phase 2}

In phase 2, our research addressed the following areas when developing a procedure that employs the IFC format to support information exchanges with BABs during seismic-authorization applications:

- Defining a strategy that uses the IFC format to reduce the seismic-authorisation deliverables required.

- Analysing the IFC format with respect to structural engineering.

- Choosing the best strategy for the integration of any required information in the IFC format.

Figure 2 depicts an outline of the approach we followed to address the above-mentioned areas.

\subsection{Using the IFC format to reduce the deliverables required for seismic-authorisation applications}

Table 2 sets out the deliverables required to apply for a seismic-authorisation permit. These commonly comprise: an application form; 2D drawings and reports with technical specifications; and additional checklists and forms. If successful, official approval documentation is issued by an officer from the $\mathrm{BAB}$ with jurisdiction over the area where a project is located. We argue that the IFC format is not able to replace administrative and legal documents like application forms and building permits (issued by other municipalities), because its structure lacks standardised 'spots' for such content. However, the buildingSMART ${ }^{\circ}$ $\mathrm{RR}$ is currently analysing the possibility of extending the IFC structure to enable it to include at least one entity (or class) that specifies the state of approval in relation to the information submitted. Even so, this would represent only a small step forward, meaning that administrative and legal documents in the paper format would still be required.

We believe that the IFC format could be better employed in reducing the amount of technical documentation required; for example, $2 \mathrm{D}$ drawings could be replaced entirely by IFC models that include sufficient detail on reinforcements and connections. This would enable $\mathrm{BAB}$ officials to use IFC viewers to explore models in detail. Commonly, technical reports are produced automatically by Finite Element Analysis (FEA) software that performs structural analyses according to a reference building code (i.e., Eurocodes) and deploys tools to design and verify structural elements. However, this software cannot produce completed checklists and forms that summarise a project's technical structural specifications, because these are rarely standardised and, therefore, depend to a great extent on the internal practices of BABs. In fact, additional checklists and forms give $\mathrm{BAB}$ officers a quick and clear overview of structural projects, although these require completion by hand by structural engineers. We argue that technical reports are essential for understanding project choices and designs, but checklists and summary forms could be replaced by an IFC model that integrates all the valuable information required. This would enable $\mathrm{BAB}$ officers to leverage IFC models, integrating the data contained in checklists in order to increase their understanding of structural projects, as they would be able to visualise models and read technical information concurrently, and use data in the IFC format to conduct preliminary counterchecks. Figure 3 depicts an information flow that could be employed to incorporate structural information in an IFC model to obtain an integrated IFC.

Additionally, the availability of IFC models in an epermitting platform could promote the use of novel workflows by $\mathrm{BAB}$ officers in their examinations of documentation that can be linked to a model's objects. In this way, IFC models would also function as a key for accessing project documentation. This would fundamentally improve current paper-based practices.

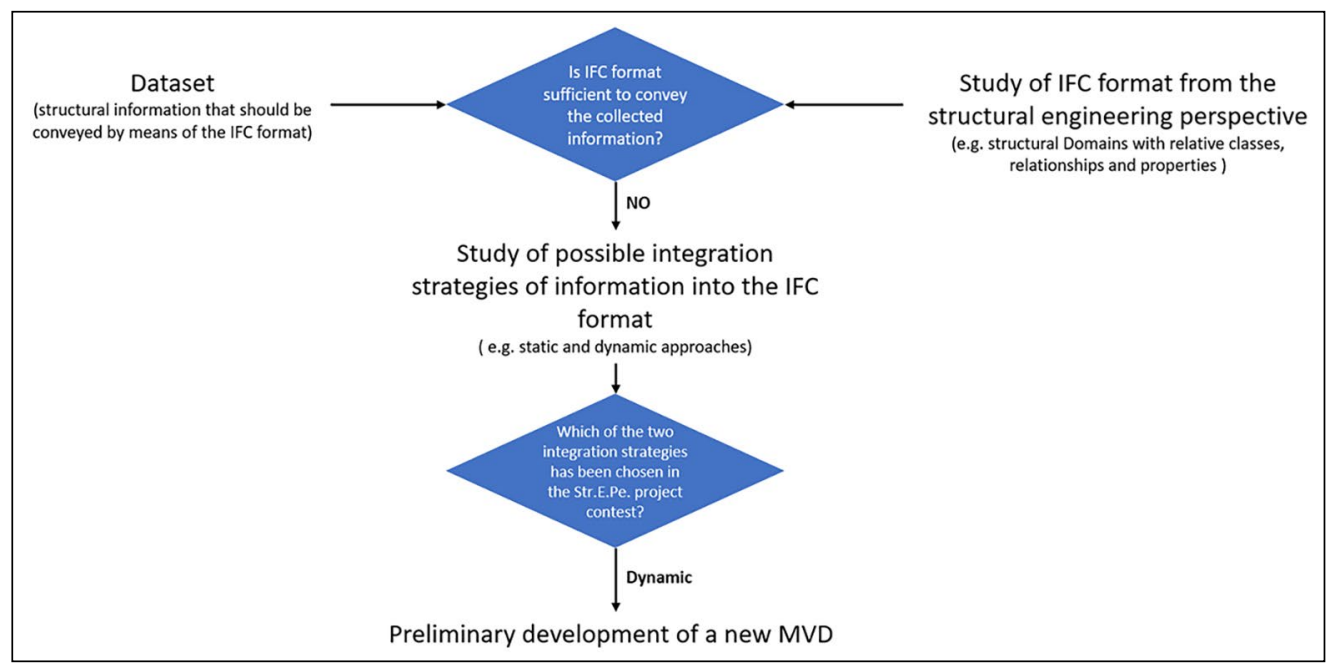

Figure 2. The reference approach of phase 2 
We believe that an integrated IFC would be a valuable deliverable when it comes to improving structural permit and approval practices. As a consequence, the following section describes a study on content that could be incorporated in the IFC format, as well as a reference integration procedure that could overcome the criticalities of the process depicted in Figure 3.

\subsection{Using the IFC format to reduce the deliverables required for seismic-authorisation applications}

We conducted research to help us to achieve a detailed understanding of the capacity of the IFC format to deliver structural engineering data, in particular the outputs of structural analyses and assessments. Our focus was on the structural aspects of the format, which integrates structural information by way of classes, attributes and properties. This occurs via concepts described within two domains and in relation to one of the four reference layers (domain layer) that make up the architecture of the standard: IfcStructuralAnalysisDomain and IfcStructuralElementsDomain. These are presented in Figure 4.

The IfcStructuralAnalysisDomain is a data schema that enables the representation of concepts that refer to the field of structural analysis and, therefore, describe 'planar and/or spatial structural analysis models which can be used by structural analysis applications' (buildingSMART International, 2021b). More precisely, the domain introduces specific classes that allow the description of concepts that refer to IFC Schema Specifications (buildingSMART International, 2021b):

- "Straight or curved structural curve elements, planar or curved structural surface elements.
- Point, curve, and surface connections and supports.

- Specifications of loadings, including point, curve, surface loads, temperature loads, their assignment to load groups, load cases and load combinations.

- Specifications of different structural analysis models in order to describe different aspects or parts of the building.

- Analysis results defined by forces and displacements."

The other data schema, IfcStructuralElementsDomain, enables the description and representation of different types of structural building elements. In fact, unlike other common building-element data schemes, this domain contains entities for representing foundations (e.g., IfcFooting and IfcPile) and structural sub-parts that are normally included in other building elements like structural reinforcements (e.g., IfcReinforcingBar, IfcReinforcingElement, IfcReinforcingMesh, and IfcTendon). Moreover, there are additional data schemas that form part of further conceptual layers constituting the IFC's schema architecture. An example is IfcSharedBldgElements, which enables the description of real construction objects like beams, columns and walls that correspond, respectively, to entities like IfcBeam, IfcColumn and IfcWall.

Unfortunately, the structure of the IFC format lacks the space for descriptions of content such as the results of structural assessments. Consequently, from a structural engineering perspective, the format mainly explores the physical reality of the structural engineering discipline (IfcStructuralElementsDomain, IfcSharedBldgElements, etc.) and the analytical context (IfcStructuralAnalysisDomain), enabling subsequent structural assessments to be conducted in dedicated applications. Accordingly, it is clear that the format is more appropriate for the characterisation of

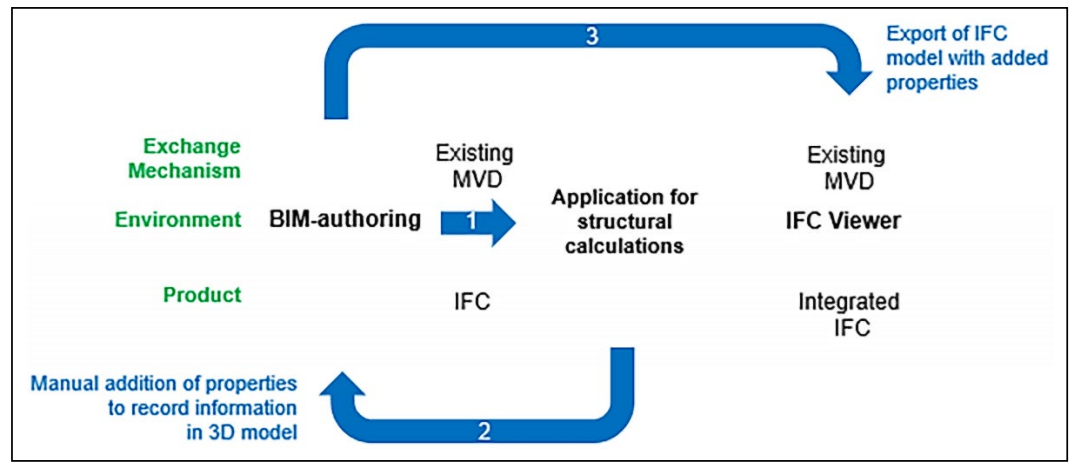

Figure 3. Possible information flow for integrating structural information into an IFC model

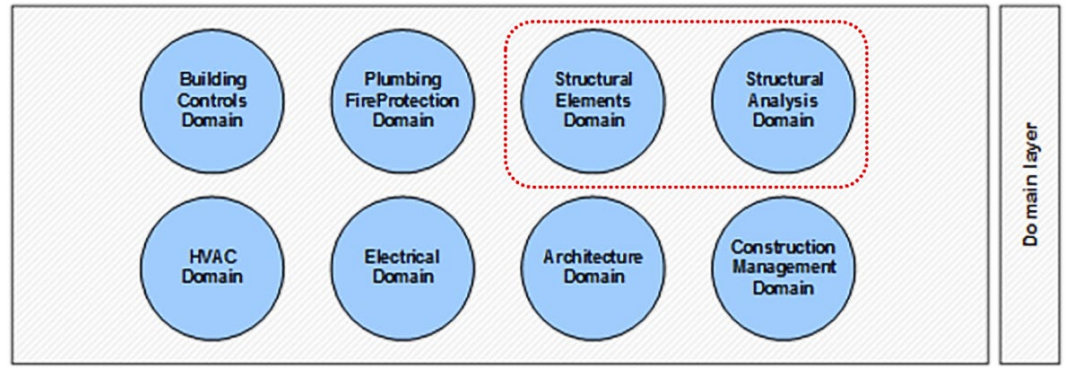

Figure 4. Domain layer of the IFC schema's architecture 
concepts that would have value for exporting a structuralanalytical model from BIM-authoring software into FEA software. This export-import activity is supported by an existing MVD: Structural Analysis View, which refers to IFC version $2 \times 3$ (buildingSMART International, 2021e). This MVD provides a subset of entities with their attributes and properties and aims to define an analytical model for use in analyses of structural calculation applications. However, the results of structural assessments cannot be recorded in the IFC format, because this lacks suitable entities, attributes and properties. Consequently, a mechanism like an MVD cannot be employed to export this information. In any event, the task of exchanging structural-assessment results is beyond the scope of the Structural Analysis View MVD and does not, therefore, have a place in it.

\begin{tabular}{|ccc|}
\hline Exchange & $\begin{array}{c}\text { Existing } \\
\text { MVD }\end{array}$ & $\begin{array}{c}\text { Nevi } \\
\text { MVD }\end{array}$ \\
Environment & BIM-authoring & $\begin{array}{c}\text { Application for } \\
\text { structural } \\
\text { calculations that } \\
\text { integrates a } \\
\text { BIM-authoring } \\
\text { environment }\end{array}$ \\
Product & IFC & IFC \\
Viewer \\
Integrated \\
IFC
\end{tabular}

Figure 5. Information flow for structural e-permits
To fill this lacuna, the IFC format requires improvement in terms of relationships, attributes and specific properties for newly added classes. This would correspond to the creation of "space" within the format for the description of structural-assessment outputs. Consequently, an IFC-based information flow could be introduced into structural-calculation applications capable of integrating with a BIM-authoring environment in order to export content from structural analyses and assessments. Such an expanded IFC format could become a standard deliverable able to improve the processes implemented by $\mathrm{BAB}$ officers to visualize, verify and check the information required for structural-permit applications. Figure 5 sets out our proposed IFC-based workflow for exchanging information with building authorities in relation to these authorizations.

\subsection{Strategies for integrating information into the IFC format}

Table 5 presents Borrmann's et al. (2018) integration strategies for use to incorporate information in the IFC format. In particular, we provide a brief description of the strategy, adoption requirements and criticalities.

The IFC format allows the adoption of both static and dynamic semantic-extension strategies. In relation to Table 5, we took the decision to adopt the second approach for the purposes of the Str.E.Pe. project. In detail, most

Table 5. Summary of strategies for use to incorporate information into the IFC format

\begin{tabular}{|c|c|c|c|c|c|}
\hline $\begin{array}{c}\text { Integra- } \\
\text { tion strat- } \\
\text { egy }\end{array}$ & $\begin{array}{l}\text { Nature/ } \\
\text { mecha- } \\
\text { nism }\end{array}$ & Description & Adoption requirements & Criticalities & $\begin{array}{c}\text { Application in } \\
\text { the Str.E.Pe. } \\
\text { project }\end{array}$ \\
\hline $\begin{array}{l}\text { Entities \& } \\
\text { attribute } \\
\text { definition }\end{array}$ & Static & $\begin{array}{l}\text { The strategy } \\
\text { involves developing } \\
\text { additional classes and } \\
\text { attributes. The latter } \\
\text { are included within } \\
\text { the schema (IFC) } \\
\text { and represent the } \\
\text { characteristics of an } \\
\text { object. }\end{array}$ & $\begin{array}{l}\text { - Broad sharing and adoption among all inter- } \\
\text { ested stakeholders. } \\
\text { - Adding specific attributes for any new class } \\
\text { that is added. These attributes represent any } \\
\text { novel features requiring consideration. }\end{array}$ & $\begin{array}{l}\text { It is not possible } \\
\text { to add all } \\
\text { the features } \\
\text { considered, as } \\
\text { this would lead } \\
\text { to schema (IFC) } \\
\text { management } \\
\text { issues. }\end{array}$ & No \\
\hline $\begin{array}{l}\text { Properties } \\
\& \\
\text { proxy } \\
\text { definition }\end{array}$ & Dynamic & $\begin{array}{l}\text { The strategy involves } \\
\text { the definition of } \\
\text { properties created } \\
\text { dynamically. This } \\
\text { is done by defining } \\
\text { individual properties } \\
\text { (IfcProperty and } \\
\text { subclasses) and } \\
\text { property sets } \\
\text { (IfcPropertySet). } \\
\text { This strategy also } \\
\text { introduces the } \\
\text { Proxy Definition } \\
\text { (i.e., IfcProxy), } \\
\text { which allows the } \\
\text { semantics of a generic } \\
\text { class to be defined } \\
\text { dynamically. }\end{array}$ & $\begin{array}{l}\text { - The stakeholders involved in an informa- } \\
\text { tion exchange (i.e., a minimum of the writ- } \\
\text { er of the information and those receiving } \\
\text { it) should agree on the meanings associated } \\
\text { with the information in terms of properties } \\
\text { or proxies. } \\
\text { - This strategy allows the use of standardised } \\
\text { properties belonging to libraries like the } \\
\text { buildingSMART data dictionary (bsDD) in } \\
\text { order to improve the management and clar- } \\
\text { ity of concepts. } \\
\text { - This strategy allows the unlimited addition } \\
\text { of properties to examples of IFC models. } \\
\text { - Both IfcPropertySet and IfcBuildingEl- } \\
\text { ementProxy allow the development of a } \\
\text { meta-model characterised by different ap- } \\
\text { proaches related to semantic extensions. } \\
\text { This makes it possible to describe a wide } \\
\text { spectrum of application scenarios. }\end{array}$ & $\begin{array}{l}\text { Different } \\
\text { stakeholders } \\
\text { define a huge } \\
\text { number of } \\
\text { arbitrary } \\
\text { concepts (both } \\
\text { objects and } \\
\text { properties) } \\
\text { for the same } \\
\text { purpose. This } \\
\text { leads to major } \\
\text { redundancy. }\end{array}$ & $\begin{array}{l}\text { Yes, the project } \\
\text { focuses on } \\
\text { the use of } \\
\text { properties. }\end{array}$ \\
\hline
\end{tabular}


BIM-authoring environments currently allow the creation and addition of properties that can be exported in the IFC format that is leveraging the dynamic mechanism. However, defining Psets needs both the stakeholders involved to agree on the content and unambiguous meanings to be associated with the added, and then exchanged, properties: i.e., structural engineers and $B A B$ officers should agree on the meaning of the new properties to be exchanged in an application for a structural permit. In the following section, we will concurrently address this issue and develop a new MVD that will allow the filtering of interested entities and those affected by the addition of the new properties we propose. This would also enable the adoption of validation processes for IFC models.

\subsubsection{Preliminary development of a new MVD for the aims of the Str.E.Pe. project}

The MVD mechanism promoted by buildingSMART is defined as "a subset of the overall IFC schema to describe a data exchange for a specific use or workflow. MVDs can be as broad as nearly the entire schema or as specific as a couple of object types and associated data" (buildingSMART International, 2021d). This presents extensive supporting technical documentation and can be implemented in the class of software applications that could be part of IFC-based information exchanges. Within the framework of the Str.E.Pe. project, we aim to develop a new MVD that would allow the delivery of IFC models to BABs. These would integrate specific information relating to structural assessments that is currently only contained in structural reports and specifications or has been collected manually for checklists and summary forms. In this section, the focus is on the definition of content for transmission in IFC models via the new MVD; meanwhile, in Section 5, we illustrate how the Str.E.Pe. project leverages the IFC models obtained with this new MVD to overhaul the process of applying for seismic authorizations. Our definition of content started with the information in Table 4 , although this only refers to newly-designed reinforced concrete structures according to the Italian building code Norme tecniche per le costruzioni - NTC 2018 (Ministero delle Infrastrutture e dei Trasporti, 2018). The information in Table 4 was obtained using software for structural calculations. To enable the addition of new properties representing the outputs of structural assessments, we examined structural applications that integrate a BIMauthoring environment. Deliberately, therefore, we do not go into detail about mapping the data from structural calculation software in the IFC format: this is beyond the scope of both this paper and the Str.E.Pe. project. Instead, we both present information that can be transferred via the dynamic mechanism of adding properties and identify the classes that would be affected by these integrations; in this way, a new MVD will be defined that will enable the IFC format to be used to present integrated IFC models to BABs. This approach allows the standardisation of the information flow. This means that all the software houses in- volved in structural-calculation applications could employ this new MVD to produce integrated IFC models whereby information extrapolated from structural reports and assessments is written in automatically in places identified by our proposed Psets.

Our work is continuing the technical development of the new MVD and the creation of the reference documentation, with the ifcdoc tool being used for this purpose (buildingSMART International, 2021c). Nevertheless, the development of an MVD that would apply to all new reinforced concrete structures faces several problems relating to:

- Reference standards: structural designs and calculations must refer to a reference standard, which depends on the country where an engineer is working. Reference codes regulate the types of assessment required; additionally, codes differ in terms of their approaches, which can be prescriptive or performancebased. This affects the quantitative and qualitative outputs of structural assessments. For this reason, we argue that, unfortunately, the particular information required for integration into an IFC standard for structural-permit applications very much depends on the reference code being considered. In this paper, however, reference is made to the Italian building code (Ministero delle Infrastrutture e dei Trasporti, 2018).

- The adopted materials and structural typologies: there are different types of reinforced concrete structure, e.g., cast-in-place, prefabricated and prestressed. We chose not to consider other structural materials simultaneously, e.g., masonry, steel, wood and hybrid configurations; design codes differentiate between such materials, because different structural elements and systems require different capacity models and structural assessment procedures. As a consequence, to avoid further complications, our focus is on reinforced concrete structures, in particular all the possible configurations of the load-bearing structure (frame, wall, mixed) and resulting structural elements (beams, columns, walls, slabs).

- The neglect of retrofit interventions in existing structures: a decision was made to focus the study on new reinforced concrete structures; in doing so, we have neglected existing structures, for which structural engineers commonly design structural retrofit interventions. The basis of the decision was the differences between the information required for new and existing buildings. The latter need two sets of outputs: one from a preliminary phase where the structural performance is assessed, and another in relation to the design and assessment of any corresponding structural retrofit interventions required. This would render the information in Table 4 ineffective. Additionally, these two phases (assessment and retrofit) may require the use of different structural-analysis methods and different capacity models. 
The issues described herein reflect the boundaries we have set for the development of a new MVD, although our approach has the potential to apply to all structural materials, as well as to existing structures. Our MVD is associated with a particular baseline (IFC4 version), which filters the entities affected by integration and information exchanges relating to some of the proposed Psets. This enables descriptions of, for example: the reinforced concrete structural typology (with frames, with frames and walls, etc.), as well as the safety factors identified by local and global assessments relating to all the limit states required by the reference building code. We have currently distinguished some of the classes affected by integration, such as IfcBuilding, IfcBuildingStorey, IfcSite, IfcBeam, IfcColumn, IfcWall, IfcStructuralConnection, IfcFooting, and IfcPile. We do not, however, exclude the possibility of identifying other classes as the work progresses. Figure 6 below contains an example of the current Psets.

Once our analysis and definition of the exchange requirements is complete (i.e., all the classes affected by information exchanges are identified and the properties to be added to them are defined), the resulting MVD will be implemented in Edilus, a structural calculation software tool that enables the incorporation of a BIM environment. This will automatically produce an integrated IFC model that includes the results of the structural assessments performed by Edilus (which extrapolates them automatically from calculation printouts).

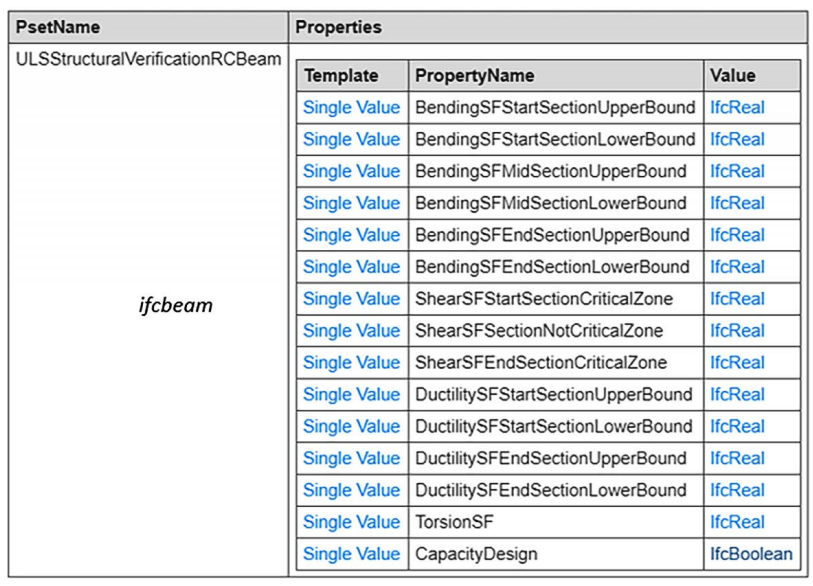

\begin{tabular}{|c|c|c|c|}
\hline \multirow{2}{*}{\begin{tabular}{|l|} 
PsetName \\
OverallStructuralRCBuildinglnformation
\end{tabular}} & \multicolumn{3}{|l|}{\begin{tabular}{|l} 
Properties \\
\end{tabular}} \\
\hline & Template & PropertyName & Value \\
\hline \multirow{12}{*}{ ifcbuilding } & Single Value & AnalysisMethod & IffLabel \\
\hline & Single Value & BuildingCategory & IfcLabel \\
\hline & Single Value & StructuralType & IfcLabel \\
\hline & Single Value & DesignWorkingLifeCategory & IfcTimeMeasure \\
\hline & Single Value & RegularitylnPlan & IfcBoolean \\
\hline & Single Value & RegularityinElevetion & IfcBoolean \\
\hline & Single Value & TorsionalDeformability & IfcBoolean \\
\hline & Single Value & P-DeltaDirX & IfcReal \\
\hline & Single Value & P-DeltaDirY & IfcReal \\
\hline & Single Value & Behaviourfactor & IfcReal \\
\hline & Single Value & DuctilityClass & IfcLabel \\
\hline & Single Value & DesignTechnicalStandard & IfcText \\
\hline
\end{tabular}

Figure 6. Examples of property sets: ifcbeam and ifcbuilding

\section{Phase 3}

\subsection{The structural e-permit workflow}

The work conducted in the previous phases was fundamental for the production of a clear framework for improving the process for seismic-authorization applications. The approach we propose implements 3D information models in the IFC format and delivers documentation in the ISO 21597-1:2020 (ISO, 2020) information container data drop (ICDD) system, all via a dedicated platform. Figure 7 depicts the process map of the Str.E.Pe. procedure, which is written in the simplified BPMN language.

The map has two pools and three lanes: the first and third lanes describe the operations carried out by the two professionals involved in the process - respectively, the structural engineer in charge of drawing up the documentation to apply for a seismic-authorization permit, and the technician from the $\mathrm{BAB}$ who is involved until the permit is issued. The second lane refers to operations carried out within the Str.E.Pe. platform. Specifically, the exchange requirements envisaged by our process are:

1. An application in an editable PDF format or an online form.

2. An ICDD comprising an IFC model, which has been integrated with Psets describing the structural project, drawings and technical specifications, as well as the connections between them.

3. An official approval document (i.e., a seismic-authorisation permit).

As seen in the process map, a structural engineer draws up the documentation required to apply for a seismic-authorisation permit. Then, after the design phase, he/she accesses the Str.E.Pe. platform and delivers a form (first exchange requirement), applying for a permit for his/ her project and an ICDD (second exchange requirement) that includes: a structural information model in the IFC format, 2D drawings, and descriptions of the connections between them. The Str.E.Pe. platform can then initiate a preliminary automated code-checking process which, if it ends positively, enables the application to advance; if the end-result is negative, the system sends an email containing feedback to the structural engineer, who is asked to review the deliverables and resubmit the ICDD. If the preliminary code-check is positive, a civil engineering technician from the relevant $\mathrm{BAB}$ conducts his/her counterchecks. If this counter-check ends positively, the process advances and the technician uploads an official approval document (third exchange requirement) to the platform; if the result is negative, the technician sends an email containing feedback to the structural engineer, who is asked to review the deliverables and resubmit the ICDD. It is worth noting that the ICDD is standardized according to ISO 21597-1:2020 (ISO, 2020), which is a forthcoming specification for a multi-model container approach that allows the models to be interlinked and the data to be connected to external sources. We have deployed an ICDD exchangecontainer to improve information exchanges between the structural engineer and the civil engineering technician during the seismic-authorization application process. 


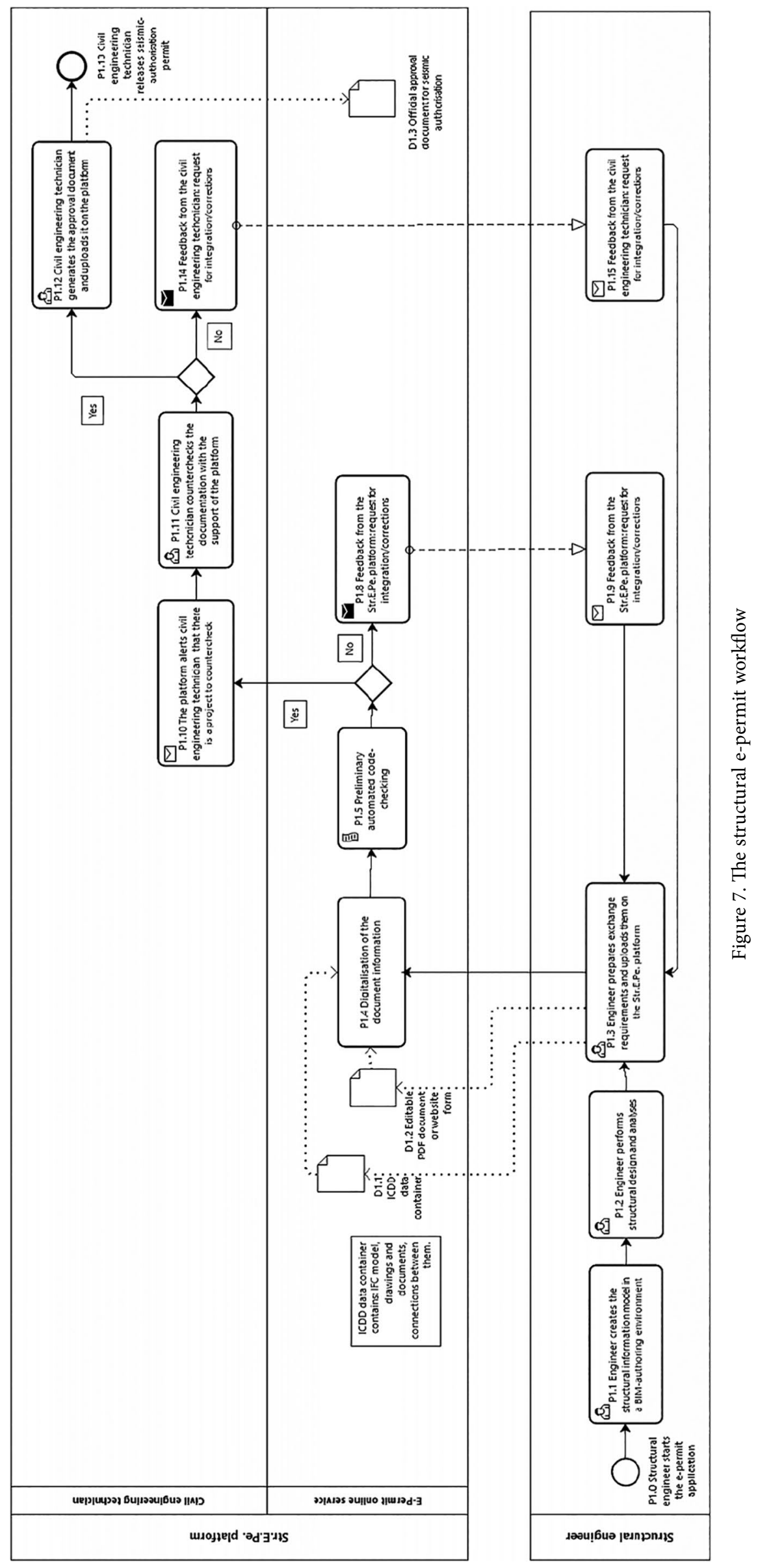


A structural-information model and related documentation (2D drawings, reports with technical specifications) are delivered in a single data drop, and connections between the model and the documents are preserved. In addition, the platform offers the possibility of implementing preliminary automatic code-checks specifically in order to validate IFC (structural) models.

\subsection{Preliminary proof-of-concept of the use of an integrated IFC model to ensure seismic requirements compliance}

In this section, we present a proof-of-concept of the use of an integrated IFC model in the Str.E.Pe. application process. The officers of the Avellino building authority have tested the proof-of-concept and assessed (qualitatively) its feasibility. Based on our advice, they used a SWOT analysis specifically on the use of an integrated IFC model that supports them in checking the compliance of the structural project with seismic requirements. However, as mentioned previously, an MVD is still under development, meaning that this preliminary proof-of-concept deploys an IFC model where information, on structural safety, has been added automatically through proprietary algorithms implemented in Edilus software by ACCA Software ${ }^{\circledR}$. In detail, we apply the Str.E.Pe process to a project renovating the school in Montemarano. This involves the deconstruction of an existing building and replacing it with a new reinforced concrete structure. Figure 8 depicts the new school's structural and architectural BIM models; the former was created with Edilus and the latter with Edificius, both of which are produced by ACCA Software ${ }^{\circledR}$.

In the Edilus environment, we defined Psets that relate to the project at both a global and a local level; next, we exported the integrated IFC model according to the MVD CV2.0 - IFC Certification Participants (buildingSMART International, 2021a). Specifically, we added information at the global level to the ifcbuilding entity, as seen in Figure 9 and, as seen in Figure 10, information at the local level to each structural element (specifically ifccolumn, ifcbeam and ifcslab entities).

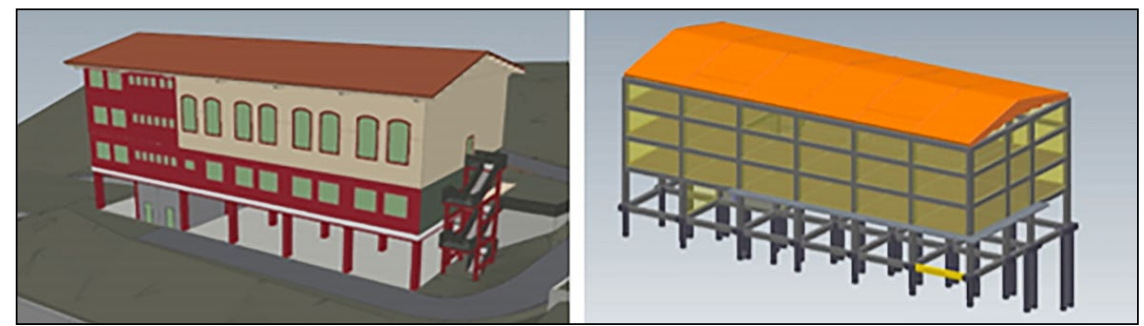

Figure 8. BIM architectural and structural models of the new school in Montemarano

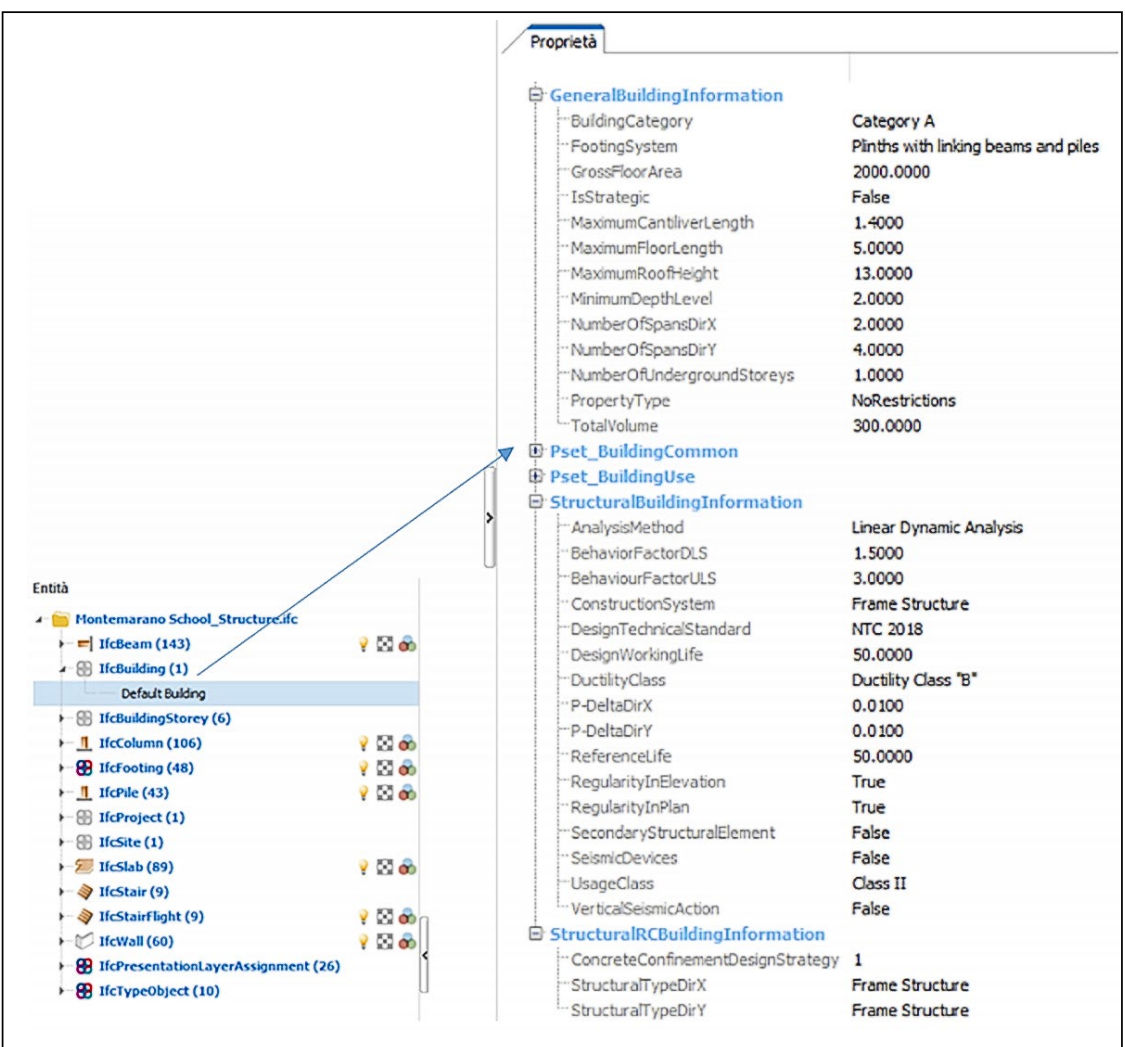

Figure 9. The Pset adds information on the structural project at the global level to the ifcbuilding entity 


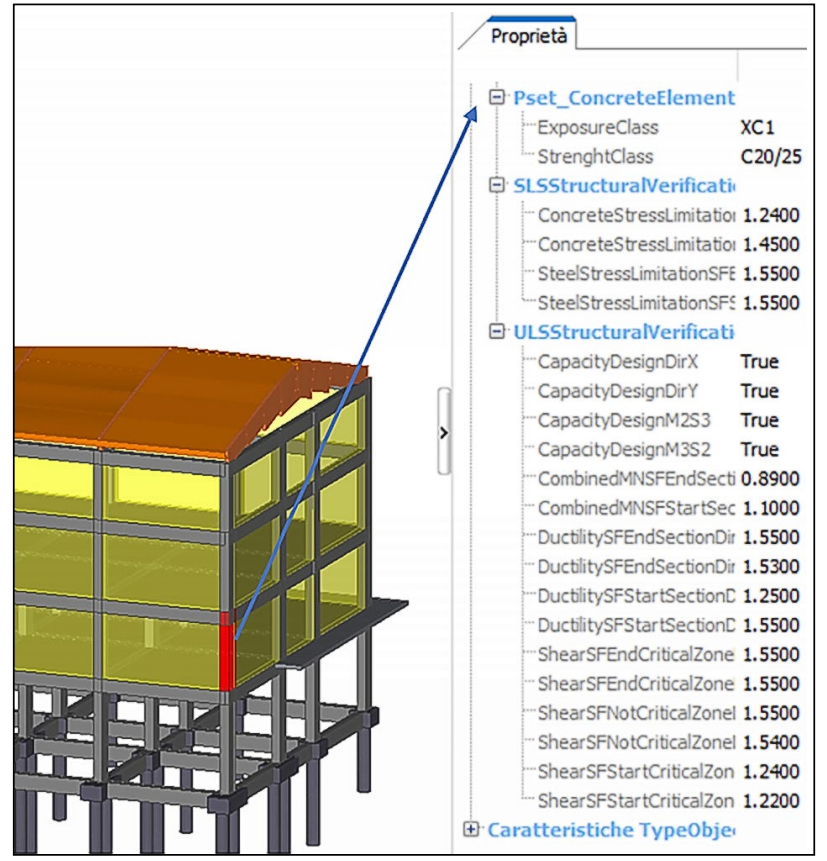

Figure 10. The Pset adds information on the structural project at the local level to the ifccolumn entity
We simulated the Str.E.Pe. submission process for the Montemarano school project using the ACCA Software usBIM.ePermit platform. After the software revealed that the automatic code-check of the safety factors (SF) had been successful (which means that all the SFs are greater than one), the officers at the building authority used the usBIM.ePermit platform to counter-check the compliance of the school structural project with seismic requirements. First, as seen in Figure 11, it can be seen that the automated code-check process was successful; they then countercheck the uploaded documentation by leveraging its links to the IFC model (see Figure 12) and using the structural information added to the Psets (see Figure 9 and Figure 10) to conduct further checks in relation to the structural reports and calculations.

The proof-of-concept ends with the officers releasing the seismic-authorisation permit (no integration required) and uploading it to the usBIM.ePermit platform. Finally, the officers assessed the feasibility of the proof-of-concept with a SWOT analysis, using IFC models to support them in assessing the compliance of structural projects with seismic requirements (see Figure 13).

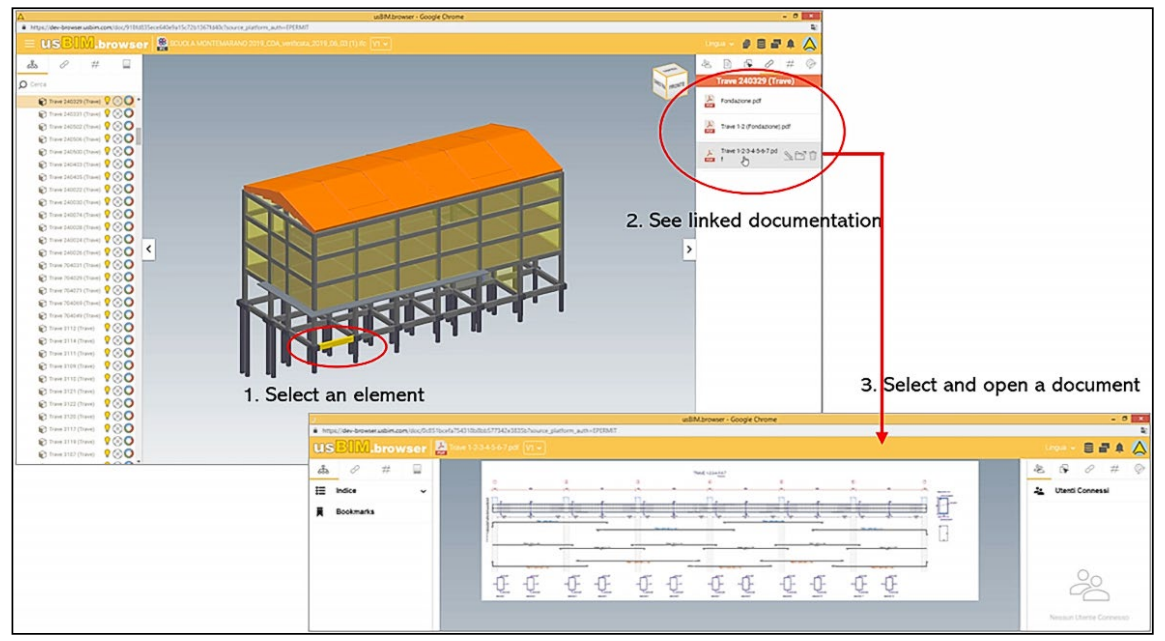

Figure 11. The usBIM.ePermit platform produces a positive outcome after the automated code-checking of the safety factors

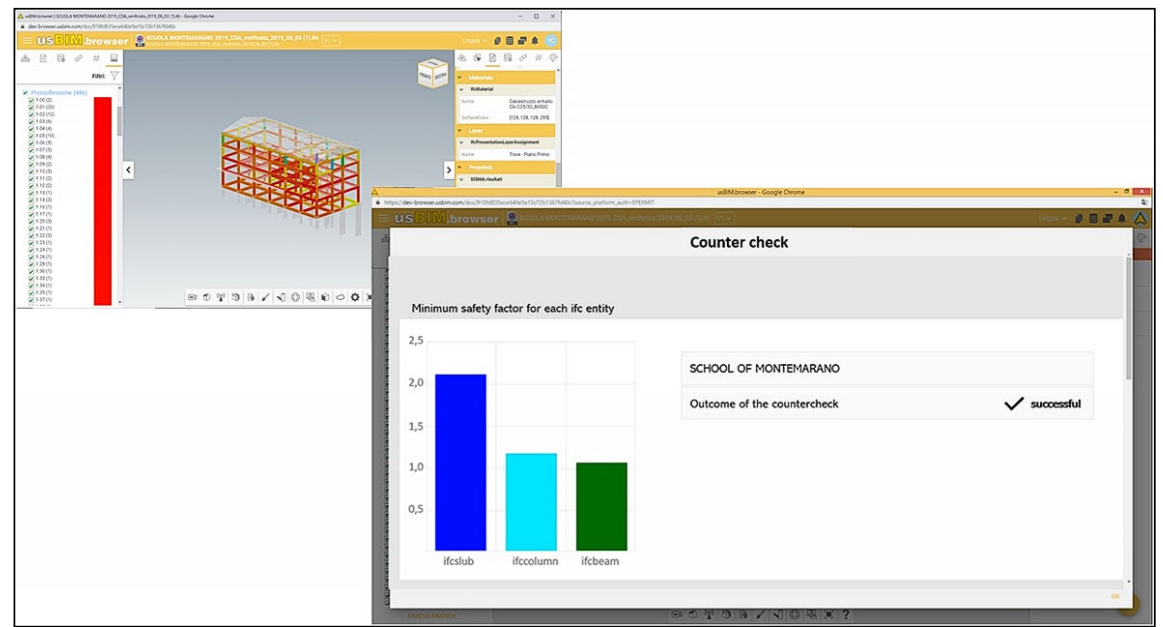

Figure 12. Example of the work of a civil engineering technician from a Building Regulatory Body using the Str.E.Pe platform 

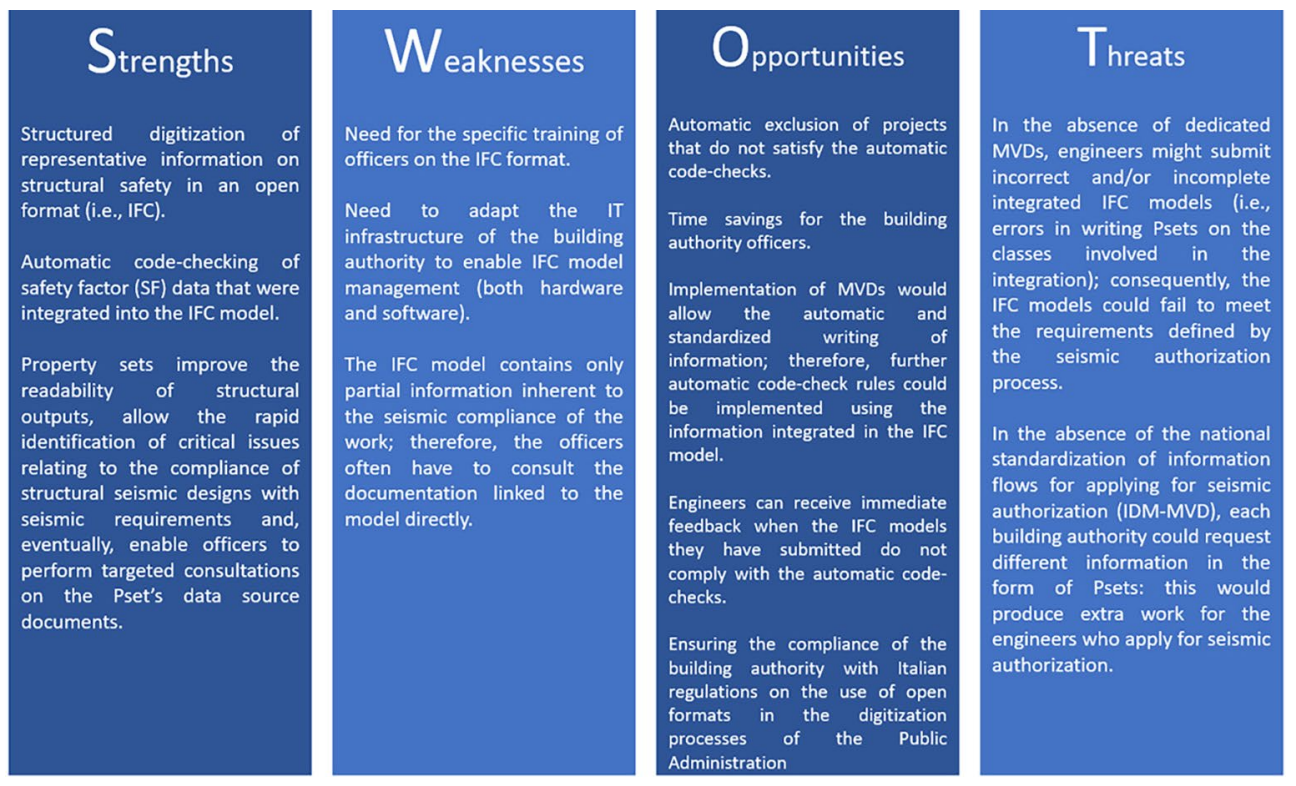

Figure 13. SWOT analysis conducted by the building authority of Avellino on using an integrated IFC model to check compliance with seismic requirements

Concerning strengths, the Avellino building officers valued the fact that the application they receive has already successfully passed an automatic code-check on the requirements of SFs greater than one. After initial work studying the IFC format and learning to use the usBIM. ePermit platform (which are the main weaknesses they encountered), the officers immediately found that visualizing information on the structural project, directly from the IFC model, was an intuitive process. In particular, they are able to access linked documentation, when necessary, but can also save time when it comes to understanding the overall setting of the structural project, which is presented in the Pset at the global level. Moreover, the local Psets enable them to achieve a preliminary understanding of the stresses to which the structural elements are subjected. However, they would prefer to only have to access documentation occasionally, and therefore think that there are opportunities for improvement in defining other automatic code-checking rules and expanding the information they can access directly from the IFC model. These improvements could save time in processing non-compliant applications and, concurrently, speed up the feedback given to the engineers applying for seismic authorization. Whether the use of an open format like IFC could also enable the building authority to comply with Italian regulations on the digitalization of processes in public offices was a further issue; the officers raised serious concerns about receiving incorrect or incomplete IFC models from the engineers making the application. They therefore support our investigation into developing an MVD that automatically and correctly exports IFC models for the seismic authorization process. They also believe that the standardisation of Psets should be done at the national level in order to avoid building authorities developing customized Psets: this would complicate and significantly increase the work of engineers.

\section{Further developments and conclusions}

It is our view that the Str.E.Pe. project fits perfectly within the current research trend of reforming processes for applications to BABs for structural engineering permits and approvals. Our focus has been on defining the information requirements for seismic-authorisation permits in Italy. This was a starting point for outlining the content that the new MVD under development would allow us to convey automatically. Currently, our work on the MVD concerns content definition and the generation of technical documentation (.mvdXML, html, etc.). We also expect to employ: 1) an additional tool like xbimXplorer (XbimXplorer, n.d.), which will make it possible to read BIM models in the IFC format (in the different versions of IFC $2 \times 3$ and IFC4); and 2) .mvdXML files to, for instance, validate the IFC schema and content in terms of entities and related properties, and query the syntax for the data extraction. Of all the available plugins, we intend to use the "buildingSMART mvdXML validation". This allows the validation of an MVD as a subset of data and the concurrent validation of property value. Once the MVD has been produced for the Str.E.Pe. project, another proof-ofconcept will be proposed to the Avellino building authority for submitting IFC models automatically integrated with Psets. Additionally, further automatic code-checks will be implemented on the usBIM.ePermit platform. Unfortunately, as long as reference codes cannot be entirely translated into rules (algorithms), and until all documentation is available in a queryable format, it is not possible to implement a completely automatic process (i.e., without $\mathrm{BAB}$ officers).

However, the work described in this paper does not aim to resolve interoperability issues between BIM-authoring software and structural calculation applications; in fact, we chose to utilise applications that can be integrated 
with a BIM environment (Edilus by ACCA Software will be used as the demonstrator). This has allowed us to avoid frustrating interoperability issues in order to investigate another, often unnoticed, major defect: the absence of a BIM-based process that simplifies the application procedure for permits pertaining to structural engineering. Resolving this would lead to more efficient and standardised processes that structural engineers could employ to interact with BABs. Our new MVD is still under development, due to the large number of issues encountered, especially as concerns the shortcomings of the IFC format for conveying the outputs of structural assessments and analyses.

In conclusion, the Str.E.Pe. project is a first attempt to convey such outputs, using a dedicated MVD for this purpose. We have focused on defining and standardising content that is integrated into openBIM models for transfer to BAB officers: this approach (finally) makes a substantial change to the traditional practices that are still based on the delivery of paper reports and technical specifications. The preliminary proof-of-concept we have deployed in collaboration with the Avellino building authority has proved that the use of integrated IFC models is feasible in the seismic-authorisation process that the building officers implement, provided an initial phase of training on the IFC format and the e-permit platform is provided. Opportunities to save time are also possible if further automatic code-checking rules are implemented. Accordingly, officers support our intention to develop an MVD for the seismic-authorisation process. This would have advantages such as: considerably improving the integration issues of the IFC format in relation to structural information, preventing misunderstandings, and, as a consequence, enhancing the clarity of information exchanges between engineers and BABs. Unfortunately, deliverables in addition to BIM models in the IFC format are required for applications for structural-engineering permits and approvals; for this reason, we will also focus on defining the information requirements of BABs according to the (recently released) EN 17412-1:2020 standard, which provides guidelines to clarify the depth of the data needed in relation to geometry, additional information, and documentation (European Committee for Standardization, 2020).

Our study proposes, for the first time, a model-based approach that implements openBIM standards to improve traditional practices that are typical in countries with areas of high seismic activity. However, buildingSMART ${ }^{\circ}$ has drawn attention to the existence of a higher level of information requirements: regulatory information requirements (RIRs) and their counterpart - regulatory information models (RIMs). Our proposal in Table 4 contains a list of all the RIRs of an application for a seismic-authorisation permit, but also highlights that the corresponding RIMs comprise different information containers: a structural BIM model in the IFC format; and an application form, 2D drawings, and reports with technical specifications in the PDF format. It is our view that incorporating information in structural BIM models is pointless unless this data can be subjected to an automated code-checking process. We therefore believe that this kind of research is fundamental for attracting the attention of regulatory bodies when it comes to identifying RIRs and translating them into machine-readable rules with which to process standardised RIMs.

\section{Acknowledgements}

The Str.E.Pe. research project won a buildingSMART ${ }^{\circ}$ International award at a ceremony held in Beijing in 2019. The Authors would like to thank Antonio Cianciulli, Guido Cianciulli and all the ACCA Software development team for their support in the production of the Str.E.Pe. platform.

\section{Author contributions}

People who contributed to the work are listed in this section along with their contributions: DA, EC and GM conceived the study and were responsible for the design and development of the project. VC, DA and AC were responsible for data collection and analysis. VC and DA were responsible for data interpretation. VC wrote the first draft of the article.

\section{Disclosure statement}

Authors have not any competing financial, professional, or personal interests from other parties.

\section{References}

Borrmann, A., Beetz, J., Koch, C., Liebich, T., \& Muhic, S. (2018). Industry foundation classes: A standardized data model for the vendor-neutral exchange of digital building models. In A. Borrmann, M. König, C. Koch, \& J. Beetz (Eds.), Building information modeling (pp. 81-126). Springer. https://doi.org/10.1007/978-3-319-92862-3_5

buildingSMART International. (2021a). IFC certification participants. https://technical.buildingsmart.org/services/certification/ifc-certification-participants/

buildingSMART International. (2021b). IFC specifications database. https://technical.buildingsmart.org/standards/ifc/ifcschema-specifications/

buildingSMART International. (2021c). IfcDoc. https://www.buildingsmart.org/standards/groups/ifcdoc/

buildingSMART International. (2021d). Model View Definition $(M V D)$ - An introduction. https://technical.buildingsmart. org/standards/ifc/mvd/

buildingSMART International. (2021e). MVD database. https:// technical.buildingsmart.org/standards/ifc/mvd/mvd-database/

California Building Standards Commission. (n.d.). https://www. dgs.ca.gov/bsc

Eirinaki, M., Dhar, S., Mathur, S., Kaley, A., Patel, A., Joshi, A., \& Shah, D. (2018). A building permit system for smart cities: A cloud-based framework. Computers, Environment and Urban Systems, 70, 175-188.

https://doi.org/10.1016/j.compenvurbsys.2018.03.006

European Committee for Standardization. (2004). Eurocode 8: Design of structures for earthquake resistance - Part 1: Gen- 
eral rules, seismic actions and rules for buildings (No. EN 1998-1:2004). https://eurocodes.jrc.ec.europa.eu/showpage. php?id=138

European Committee for Standardization. (2020). Building Information Modelling - Level of information need - Part 1: Concepts and principles (No. EN 17412-1). https://standards.iteh. ai/catalog/standards/cen/af601b9e-64f1-4eeb-acca-14d626a3fada/en-17412-1-2020

Government New Zealand. (n.d.). Building performance. https:// www.building.govt.nz/

International Organization for Standardization. (2018). Industry Foundation Classes (IFC) for data sharing in the construction and facility management industries - Part 1: Data schema (ISO Standard No. 16739-1:2018). https://www.iso.org/standard/70303.html

International Organization for Standardization. (2020). Information container for linked document delivery - Exchange specification - Part 1: Container (ISO Standard No. 21597-1:2020). https://www.iso.org/standard/74389.html

Istituto Nazionale di Geofisica e Vulcanologia. (n.d.). I dati online della pericolosità sismica in Italia. http://esse1.mi.ingv.it/

Lee, Y.-C., Eastman, C. M., \& Lee, J.-K. (2015). Validations for ensuring the interoperability of data exchange of a building information model. Automation in Construction, 58, 176-195. https://doi.org/10.1016/j.autcon.2015.07.010

Lee, Y. C., Solihin, W., \& Eastman, C. M. (2019). The mechanism and challenges of validating a building information model regarding data exchange standards. Automation in Construction, 100, 118-128. https://doi.org/10.1016/j.autcon.2018.12.025

Los Angeles Department of Building and Safety. (n.d.). Plan check \& permit. https://www.ladbs.org/services/core-services/ plan-check-permit

Ministero delle Infrastrutture e dei Trasporti, (2018). Decreto 17 gennaio 2018 Aggiornamento delle «Norme tecniche per le costruzioni».

https://www.gazzettaufficiale.it/eli/id/2018/2/20/18A00716/sg

Muto, M. (Ed.). (2020). e-submission common guidelines for introduce BIM to building process - e-submission common guidelines for introduce BIM to building process (Technical Report No. RR-2020-1015-TR). buildingSMART International.

Organization for Earthquake Planning and Protection (OASP). (2000). Greek earthquake regulation (EAK-2000) (in Greek). https://www.oasp.gr/node/8

Ramaji, I. J., \& Memari, A. M. (2018). Interpretation of structural analytical models from the coordination view in building information models. Automation in Construction, 90, 117-133. https://doi.org/10.1016/j.autcon.2018.02.025

Reitherman, R. (2012). Earthquakes and engineers: An international history. ASCE Press. https://doi.org/10.1061/9780784410714

Santos, R., Costa, A. A., Silvestre, J. D., \& Pyl, L. (2019). Integration of LCA and LCC analysis within a BIM-based environment. Automation in Construction, 103, 127-149.

https://doi.org/10.1016/j.autcon.2019.02.011

Seismic Resilience. (n.d.). Codified seismic design. http://www. seismicresilience.org.nz/topics/resilient-design/codified-seismic-design/

Shahi, K., McCabe, B. Y., \& Shahi, A. (2019). Framework for automated model-based e-permitting system for municipal jurisdictions. Journal of Management in Engineering, 35(6), 04019025.

https://doi.org/10.1061/(ASCE)ME.1943-5479.0000712
Venugopal, M., Eastman, C. M., Sacks, R., \& Teizer, J. (2012). Semantics of model views for information exchanges using the industry foundation class schema', Advanced engineering informatics. Advanced Engineering Informatics, 26(2), 411-428. https://doi.org/10.1016/j.aei.2012.01.005

Wang, X. (2014). BIM handbook: A guide to Building Information Modeling for owners, managers, designers, engineers and contractors. Construction Economics and Building, 12(3), 101-102. https://doi.org/10.5130/AJCEB.v12i3.2749

Whitell, M., Cao, Y., McCabe, B. Y., \& Shahi, A. (2020). Standardizing Ontario's permitting process for e-permitting implementation. In Construction Research Congress 2020: Project Management and Controls, Materials, and Contracts (pp. 1339-1348). American Society of Civil Engineers Reston, VA. https://doi.org/10.1061/9780784482889.143

XbimXplorer. (n.d.). https://docs.xbim.net/downloads/xbimxplorer.html 